EXCHANGE RATE DYNAMICS

2005 IN ECONOMIES WITH PORTEOLIO RIGIDITIES

Beatriz de-Blas-Perez

Documentos de Trabajo.

N. 0532

baNeode españa 
EXCHANGE RATE DYNAMICS IN ECONOMIES WITH PORTFOLIO RIGIDITIES 


\title{
EXCHANGE RATE DYNAMICS IN ECONOMIES WITH PORTFOLIO \\ RIGIDITIES (*)
}

\author{
Beatriz de-Blas-Pérez $\left(^{* *}\right)$
}

UNIVERSIDAD DE NAVARRA

(*) Acknowledgements: this work is part of a research project financed by the Bank of Spain and initiated during my stay as a research fellow there. I thank seminar participants at the Bank of Spain, Universidad Carlos III de Madrid, and 2004 ZEI Summer School on Monetary Theory and Policy. Special thanks to comments by Jim Costain and an anonymous referee. Also thanks to Klaus Desmet, Ignacio Hernando, David López-Salido, Eva Ortega, Gabriel Pérez-Quirós, and Javier Vallés. Financial support from MCYT Research Fellowship (SEC2002-04318-C02-02) is gratefully acknowledged. The usual disclaimer applies.

${ }^{(*)}$ Departamento de Economía, Universidad de Navarra, Edificio Bibliotecas - Entrada Este, 31080 Pamplona (Navarra), SPAIN. E-mail address: beatriz.blas@uc3m.es 
The Working Paper Series seeks to disseminate original research in economics and finance. All papers have been anonymously refereed. By publishing these papers, the Banco de España aims to contribute to economic analysis and, in particular, to knowledge of the Spanish economy and its international environment.

The opinions and analyses in the Working Paper Series are the responsibility of the authors and, therefore, do not necessarily coincide with those of the Banco de España or the Eurosystem.

The Banco de España disseminates its main reports and most of its publications via the INTERNET at the following website: http://www.bde.es.

Reproduction for educational and non-commercial purposes is permitted provided that the source is acknowledged.

\section{(c) BANCO DE ESPAÑA, Madrid, 2005}

ISSN: 0213-2710 (print)

ISSN: 1579-8666 (on line)

Depósito legal:

Imprenta del Banco de España 


\section{Abstract}

This paper analyzes the international monetary transmission mechanism in economies with portfolio rigidities. In a general equilibrium monetary model with distribution costs in trade, I analyze the reaction of the economy to technology, money supply and government spending shocks, and the ability of the model to account for some stylized facts of international business cycles. The main focus is on interest rate and exchange rate dynamics.

In contrast to most limited participation models, the specification employed in this paper is able to replicate the liquidity effect and the effect of money shocks on international interest rates spreads. It also reports both a nominal and real depreciation of the domestic currency after a money injection, as observed in the data. Quantitatively, the model does relatively well in matching some business cycle moments but fails to generate the high volatility and correlations of exchange rates observed in the data.

Keywords: flexible prices, distribution costs, exchange rate dynamics.

JEL: F10; F31; F41 


\section{Introduction}

Theoretical approaches to the analysis of the international transmission of shocks have usually employed models with price rigidities to explain the economic interactions across countries in response to shocks. These models have achieved some success reporting high (but still lower than in the data) volatility of exchange rates (Kollmann, 2001).

In contrast, in this paper I analyze the international transmission of shocks across countries in a flexible price general equilibrium model with portfolio rigidities. In this model, households cannot adjust their portfolio immediately in response to shocks. This limited participation of households in financial markets is the portfolio rigidity that makes money have real effects.

Previous work with limited participation models has failed to reproduce the dynamics of interest rate and exchange rates after a monetary supply shock. For example, Schlagenhauf and Wrase (1995) use a limited participation framework to study the effects of money supply shocks in an open economy. They need to add another friction (sluggish capital) to reproduce the dynamics of interest rates and exchange rates after a monetary injection, but even then they report lower volatilities for these variables than in the data. Furthermore, these models have difficulty in generating the high relative standard deviation and persistence of the exchange rates with respect to output observed in the data.

The model used here differs from previous limited participation literature in two ways. First, unlike Schlagenhauf and Wrase (1995), in this paper households are not required to hold two different currencies in order to purchase domestic and foreign goods. Instead, households in the domestic country only need to hold their domestic currency and can use it to purchase a consumption basket made out of a combination of domestic and foreign consumption goods.

Second, distribution costs in the transportation of imported consumption goods are introduced. In particular, I will consider two different structures of distribution costs: the traditional iceberg costs (according to which part of the imported product is lost during transport) and what I call below delivery costs (which assumes that domestic resources are needed for transporting imports to the market place as in Burnstein, Neves and Rebelo (2003)). Notice that with these costs at work, purchasing power parity (PPP) no longer holds, without having to resort to any nominal rigidity.

With these elements, I evaluate the ability of this flexible price monetary model to replicate some stylized facts of open economies, with emphasis on interest rates and exchange rate dynamics. The model presented here is able to replicate the liquidity effect and increased spreads between foreign and domestic interest rates in response to a positive domestic money supply shock, as observed in the data. Regarding exchange rate dynamics, the economy can account for both the nominal and real depreciation of the domestic currency after a monetary injection 
at home. However, while this is an improvement compared with previous limited participation models, the model fails quantitatively in generating sufficiently volatile nominal and real exchange rates, meaning that further work needs to be done in this direction.

The structure of the paper goes as follows. In Section 2, I present some stylized facts on international business cycles. Sections 3 to 5 report the model, equilibrium conditions and parameterization of the economy. In Section 6 I investigate the effects of fiscal, monetary and technology shocks and study the business cycles generated by the model. I discuss the results in Section 7. Finally, Section 8 closes the paper.

\section{Some stylized facts of international business cycles}

In this section, I review some of the stylized facts on international economic fluctuations for the USA, Japan, France and UK. This analysis of the data will be useful to assess the performance of the monetary model described below. The time period considered goes roughly from 1978:1 to 2001:2, depending on the country, and is characterized by flexible exchange rates. Data are obtained from the OECD Main Economic Indicators on a quarterly basis. All data are in logs and detrended (except the nominal interest rate) using the Hodrick-Prescott filter.

Some key statistics for these countries are reported in Table 1. The first part of the table shows the relative standard deviations of the main macroeconomic variables with respect to output. Countries all look considerably alike in most of the statistics reported. In all cases investment and net exports are clearly more volatile than output. The opposite is true for consumption, with UK being an exemption. For the three countries the nominal exchange rate is much more volatile than output and the real exchange rate is also volatile, though somewhat less so. Money is about twice as volatile as output in all countries except the UK, and the variability of the interest rate is similar to that of $\log$ GDP.

The second part of the table reports the correlations of the same variables with each country's own output. Data show high procyclicality of consumption and investment. Money and interest rates are also procyclical, while the price level appears countercyclical, although this is not clear in all countries I study. Regarding international variables, net exports are clearly countercyclical, as are real exchange rates for most of the countries I consider (domestic goods are relatively cheaper when domestic output is higher). ${ }^{1}$ However, like Kollmann (2001), I find no clear correlation between output and nominal exchange rates. For Japan, the nominal exchange rate is countercyclical (the yen tended to appreciate when Japanese output was low), but for the UK

\footnotetext{
${ }^{1}$ For clarity, I will always define nominal exchange rates as the dollar price of each foreign currency. Likewise, real exchance rates refer to the price of foreign goods in units of US goods.
} 
the nominal exchange rate is procyclical (the pound tended to appreciate when British output was high), and for France the correlation is approximately zero.

Table 1 also shows a high degree of autocorrelation of output, nominal and real exchange rates in all countries. The last stylized fact worth mentioning here is the high correlation between nominal and real exchange rates.

In addition to the analysis of second moments, the data can be used to evaluate the reaction to shocks generated by the model. To this end, I compute VAR representations of the data and study the response of the economy to monetary policy shocks in the US.

I follow Schlagenhauf and Wrase (1995) and use the standard identification approach for monetary policy shocks: orthogonalized innovations to the Federal Funds Rate (FFR) in the US. I estimate VARs for the US vis-à-vis each foreign country (France, Japan and the United Kingdom), and use the following Wold ordering of variables: FFR, Foreign Interest Rate, the US consumer price index $\left(\mathrm{P}^{U S A}\right)$, a Foreign Price Index, the US GDP $\left(\mathrm{Y}^{U S A}\right)$, Foreign GDP, Nominal Exchange rates (units of domestic currency (US dollar) per foreign currency). ${ }^{2}$ Alternative orderings of the variables (not reported here) yield similar results. The analysis of lag determination uses the Akaike and Schwartz information criteria (AIC and BIC respectively) and yield four lags in the VAR estimation.

Figures 1 to 3 report the responses of these variables to an expansionary monetary policy shock. The solid lines are the impulse response functions and the dashed lines the estimated error bands. ${ }^{3}$ The plots show that after a negative innovation in the Federal Funds Rate (a positive monetary policy shock), nominal interest rates also fall in the foreign country, but by less, so that the interest rate differential increases. The fall in the federal funds rate causes US output to increase (significantly for the US/France and the US/UK regressions) after a lag of several quarters. Eichenbaum and Evans (1995) report similar correlations in reaction to a negative monetary policy shock for the US.

Regarding prices, both domestic and foreign prices fall after the monetary policy shock. In the literature this reaction of prices is called the price puzzle: an exogenous fall in interest rates (or increase in money supply) should cause an increase in the price index, not a decline. Some authors (Christiano and Eichenbaum (1995)) argue that the negative reaction of prices is due to missing variables in the VAR and can be solved by introducing a commodity price index or an asset price that captures the fall in inflation. However, this is does not always suffice

\footnotetext{
${ }^{2}$ Data on US and foreign GDP, price indices, nominal interest rates and nominal exchange rates are obtained from $O E C D$ Database, except for the UK nominal interest rate that is taken from the Bank of England.

${ }^{3}$ Standard error bands are computed with a Monte Carlo bootstrap method over 10,000 simulations. The sample sizes used are 1978:1-2001:2 for the US and France, and 1980:1-2001:2 for the estimated VARs for the US vis-à-vis Japan and the UK.
} 
to resolve the puzzle. Barth and Ramey (2001) identify this reaction as evidence of the cost channel of transmission of monetary policy. A fall in nominal interest rates affects both demand and supply, reducing the cost of inputs on the supply side or the cost of holding inventories, for example, and this is passed through to prices, acting as a negative cost shock. In the estimation performed here, no commodity price index is included. Thus in the model below, the existence of a cost channel is the most reasonable interpretation of the reaction of prices.

Finally, Eichenbaum and Evans (1995) and Schlagenhauf and Wrase (1995) also report that a fall in Federal Funds rate induces a sustained depreciation of the US dollar. The point estimates reported here also show this effect, which is significant on impact in the VAR with France, and after a lag in the VAR with Japan. Moreover, I obtain significant and highly persistent nominal and real depreciations as well.

In the following sections, I develop a flexible price general equilibrium monetary model in order to analyze the dynamics of this fictitious economy and compare it with the stylized facts found in the data.

\section{The Model}

In this economy there are two countries of equal size, Home and Foreign. The two countries have identical preferences and technology. Variables referring to the Foreign country are denoted by an asterisk.

Each country is composed of households, firms, financial intermediaries, and a domestic monetary authority. ${ }^{4}$ Only consumption goods are traded. Within each country households consume a composite of the Home and Foreign goods. Labor input is immobile across countries, but not capital.

Firms in both countries hire people and rent capital from households to produce a homogeneous good. They have no initial funds so they borrow the wage bill from their own country's financial intermediaries. Home firms are affected by a technology shock to production.

The model of Schlagenhauf and Wrase (1995) shares the same basic features of limited participation as this paper. Their model differs from mine in the way they open the economy. They assume that in order to buy foreign consumption goods, households need to hold foreign currency, which they obtain in the exchange market at the beginning of the period at a price $e_{t}$, the nominal exchange rate. In contrast to that setup, I assume (as do most open-economy macro papers) that households in each country have access to a composite of consumption goods made

\footnotetext{
${ }^{4}$ For simplicity, I adopt Lucas' terminology and deal with families in each country composed of different agents. This family splits early in the morning to play separate roles, and gather at the end of the day to share all their earnings.
} 
out of domestic and foreign goods. Households only need domestic currency for both types of purchases. I assume that final goods firms import foreign consumption goods, by trading directly with foreign firms. Any difference in value between imports and exports is covered by exchanging domestic bonds at the nominal exchange rate. In addition, I introduce distribution costs in this flexible price model, breaking the law of one price that holds in Schlagenhauf and Wrase's model.

At each moment the state of the economy is defined by $s_{t}$, whose history is given by $s^{t}=\left\{s_{0}, \ldots, s_{t}\right\}$ with probability $\pi\left(s^{t}\right)$. This information structure will apply to all variables except for the choice of deposits. I will assume limited participation of households in financial markets, this means that they will choose how much money to deposit at the bank depending on last period's information set, $s_{t-1}$, with history $s^{t-1}=\left\{s_{0}, \ldots, s_{t-1}\right\}$, and therefore with probability $\pi\left(s^{t-1}\right)$. In all cases, the initial realization $s_{0}$ is given.

Below, I describe the agents in the Home country. Those equations referring to the Foreign country are reported in the appendix.

\subsection{Households}

There is a continuum of infinite-lived households in the interval $[0,1]$ in each country. The representative household at Home chooses consumption, $C\left(s^{t}\right)$; labor supply, $L\left(s^{t}\right)$; and deposits, ${ }^{5}$ $\bar{D}\left(s^{t-1}\right)$; to maximize the expected value of discounted future utilities given by

$$
\max _{C\left(s^{t}\right), N\left(s^{t}\right), \bar{D}\left(s^{t-1}\right)} E_{0} \sum_{t=0}^{\infty} \beta^{t} U\left[C\left(s^{t}\right), L\left(s^{t}\right)\right],
$$

where $E_{0}$ denotes the expectational operator conditional on the time 0 information set, and $\beta \in(0,1)$ is the household's subjective discount factor. Households consume a composite of the Home, $C_{H}$, and the Foreign goods, $C_{F}$,

$$
C\left(s^{t}\right)=C_{H}^{1-\gamma}\left(s^{t}\right) C_{F}^{\gamma}\left(s^{t}\right),
$$

where the parameter $\gamma$ denotes the degree of openness. The utility function is given by

$$
U\left[C\left(s^{t}\right), L\left(s^{t}\right)\right]=\frac{C\left(s^{t}\right)^{1-\theta}-1}{1-\theta}-\Psi \frac{L\left(s^{t}\right)^{1+\psi}}{1+\psi},
$$

where $\theta$ denotes the inverse of the constant intertemporal elasticity of consumption, and $\psi$ is the inverse of the labor supply elasticity with respect to real wages, assumed to be constant. The representative household begins time $t$ with money holdings from the previous period, $\bar{M}\left(s^{t-1}\right)$.

\footnotetext{
${ }^{5}$ Henceforth, upper bar letters will denote nominal variables not normalized. Plain upper case letters will denote nominal variables once normalized. And lower case letters will refer to the growth rates of variables.
} 
At the beginning of the period, a fraction of these money holdings is allocated to deposits at the bank, $\bar{D}\left(s^{t-1}\right)$. These transactions are done in the domestic currency. In this setup, household's deposits, $\bar{D}\left(s^{t-1}\right)$, are chosen before the state of the economy is known reflecting the limited participation character of the model. This disables households from responding to a current shock by changing deposits within the same period, and induces the liquidity effect of a money supply shock on the nominal interest rate observed in the data. ${ }^{6}$

Households supply elastically labor to firms and receive in return wage payments, $\bar{W}\left(s^{t}\right) L\left(s^{t}\right)$, that can be spent within the same period. ${ }^{7}$ This wage income plus money holdings minus deposits is devoted to consumption purchases, $\bar{P}\left(s^{t}\right) C\left(s^{t}\right)$, as reflected in the following cash-in-advance constraint:

$$
\bar{M}\left(s^{t-1}\right)-\bar{D}\left(s^{t-1}\right)+\bar{W}\left(s^{t}\right) L\left(s^{t}\right) \geq \bar{P}\left(s^{t}\right) C\left(s^{t}\right) .
$$

Monetary funds flow from time $t$ to time $t+1$ according to

$$
\begin{aligned}
\bar{M}\left(s^{t}\right) & =\bar{M}\left(s^{t-1}\right)-\bar{D}\left(s^{t-1}\right)+\bar{W}\left(s^{t}\right) L\left(s^{t}\right)-\bar{P}\left(s^{t}\right) C\left(s^{t}\right)-\bar{P}_{H}\left(s^{t}\right) Z\left(s^{t}\right)+\bar{Q}\left(s^{t}\right) K\left(s^{t-1}\right) \\
& +R^{D}\left(s^{t}\right) \bar{D}\left(s^{t-1}\right)+\bar{\Pi}^{F I}\left(s^{t}\right)+\bar{\Pi}^{F}\left(s^{t}\right)-\bar{P}_{H}\left(s^{t}\right) T_{t}
\end{aligned}
$$

with

$$
Z\left(s^{t}\right)=K\left(s^{t}\right)-(1-\delta) K\left(s^{t-1}\right) .
$$

Equation (5) says that at the end of the period, all the money in the economy goes back to the household's hands. That is, he gets what remains from consumption and capital purchases, $\bar{P}\left(s^{t}\right) C\left(s^{t}\right)+\bar{P}_{H}\left(s^{t}\right) Z\left(s^{t}\right)$, and deposits at the bank, $\bar{D}\left(s^{t-1}\right)$, plus wage income, $\bar{W}\left(s^{t}\right) L\left(s^{t}\right)$, capital rents, $\bar{Q}\left(s^{t}\right) K\left(s^{t-1}\right)$, at a price $\bar{Q}\left(s^{t}\right)$, principal plus interest from deposits at the gross rate $R^{D}\left(s^{t}\right)$, profits from firms, $\bar{\Pi}^{F}\left(s^{t}\right)$, and those from the financial intermediary, $\bar{\Pi}^{F I}\left(s^{t}\right)$, which he owns. Finally, households must pay lump sum taxes, $T_{t}$, that finance government spending.

The representative household maximizes (1) subject to (2), (4), (6) and (5). The optimal choices are

$$
\begin{gathered}
\frac{\bar{W}\left(s^{t}\right)}{\bar{P}\left(s^{t}\right)}=-\frac{U_{L}\left(s^{t}\right)}{U_{C}\left(s^{t}\right)}, \\
E\left[\frac{U_{c}\left(s^{t}\right)}{\bar{P}\left(s^{t}\right)} \mid s^{t-1}\right]=\beta E\left[R^{D}\left(s^{t}\right) \frac{U_{c}\left(s^{t+1}\right)}{\bar{P}\left(s^{t+1}\right)} \mid s^{t-1}\right],
\end{gathered}
$$

\footnotetext{
${ }^{6}$ The mechanism is the following. After a money injection, there is an excess liquidity in the economy that needs to be absorbed to reestablish equilibrium. Households cannot change their portfolio choice until the following period, therefore firms are the only agents able to clear the money market. The central bank achieves money market clearing by reducing the interest rate so that firms are willing to borrow the excess amount of funds. For a formal explanation see Fuerst (1992).

${ }^{7}$ By allowing households to spend their wage earnings within the same period the impact of inflation on employment is eliminated. For more details on this, see Christiano and Eichenbaum (1992).
} 


$$
\begin{gathered}
\bar{P}_{H}\left(s^{t}\right) E\left[\frac{U_{c}\left(s^{t+1}\right)}{\bar{P}\left(s^{t+1}\right)} \mid s^{t}\right]=\beta E\left\{\frac{U_{c}\left(s^{t+2}\right)}{\bar{P}\left(s^{t+2}\right)}\left[\bar{Q}\left(s^{t+1}\right)+(1-\delta) \bar{P}_{H}\left(s^{t+1}\right)\right] \mid s^{t}\right\} \\
\bar{P}_{H}\left(s^{t}\right) C_{H}\left(s^{t}\right)=(1-\gamma) \bar{P}\left(s^{t}\right) C\left(s^{t}\right) \\
\bar{P}_{F}\left(s^{t}\right) C_{F}\left(s^{t}\right)=\gamma \bar{P}\left(s^{t}\right) C\left(s^{t}\right)
\end{gathered}
$$

and from the cost minimization, the consumer price index, $\bar{P}\left(s^{t}\right)$,

$$
\bar{P}\left(s^{t}\right)=\frac{\bar{P}_{H}^{1-\gamma}\left(s^{t}\right) \bar{P}_{F}^{\gamma}\left(s^{t}\right)}{(1-\gamma)^{1-\gamma} \gamma^{\gamma}}=\kappa \bar{P}_{H}^{1-\gamma}\left(s^{t}\right) \bar{P}_{F}^{\gamma}\left(s^{t}\right),
$$

with

$$
\kappa=\frac{1}{(1-\gamma)^{1-\gamma} \gamma^{\gamma}}
$$

Households are symmetric across countries, so the corresponding first order conditions apply to Foreign households as reported in the Appendix.

\section{$3.2 \quad$ Firms}

Firms in each economy produce a homogeneous good, $Y\left(s^{t}\right)$. Production requires the use of labor, $H\left(s^{t}\right)$, and capital, $K\left(s^{t-1}\right)$, as inputs through the following production function

$$
Y\left(s^{t}\right)=A_{t} H\left(s^{t}\right)^{\alpha_{h}} K\left(s^{t-1}\right)^{\alpha_{k}},
$$

where $A_{t}$ is the aggregate technology shock that evolves as

$$
A_{t}=A_{t-1}^{\rho_{a}} \exp \left(\varepsilon_{a, t}\right)
$$

where $\rho_{a}$ is the autocorrelation of the shock, and $\varepsilon_{t}$ is an i.i.d. exogenous disturbance. Firms own no initial funds so they borrow from the financial intermediary the wage bill, $\overline{\mathcal{L}}\left(s^{t}\right)$, at the gross interest rate, $R^{\mathcal{L}}\left(s^{t}\right)$. Firms only get indebted in their home currency. Additionally, firms are in charge of importing foreign goods for domestic consumption. To do that, they buy (sell) nominal bonds which are in zero net supply, $\bar{B}\left(s^{t}\right)$, to cover the extra amount sold (bought) of $C\left(s^{t}\right)$. These bonds cost an interest rate $R^{B}\left(s^{t}\right)$.

These perfectly competitive firms solve the following maximization problem:

$$
\max _{H\left(s^{t}\right), K\left(s^{t-1}\right), \bar{B}\left(s^{t}\right), \bar{L}\left(s^{t}\right)} E_{0} \sum_{t=0}^{\infty} \Lambda\left(s^{t+1}\right) \bar{\Pi}^{F}\left(s^{t}\right)
$$

where

$\bar{\Pi}^{F}\left(s^{t}\right)=\bar{P}_{H}\left(s^{t}\right) Y\left(s^{t}\right)-\bar{W}\left(s^{t}\right) H\left(s^{t}\right)-\bar{Q}\left(s^{t}\right) K\left(s^{t-1}\right)-\left[R^{\mathcal{L}}\left(s^{t}\right)-1\right] \overline{\mathcal{L}}\left(s^{t}\right)+\bar{B}\left(s^{t}\right)-R^{B}\left(s^{t-1}\right) \bar{B}\left(s^{t-1}\right)$, 
subject to

$$
\begin{gathered}
Y\left(s^{t}\right)=A_{t} H\left(s^{t}\right)^{\alpha_{h}} K\left(s^{t-1}\right)^{\alpha_{k}}, \\
\overline{\mathcal{L}}\left(s^{t}\right) \geq \bar{W}\left(s^{t}\right) H\left(s^{t}\right), \\
\bar{B}\left(s^{t}\right)=R^{B}\left(s^{t-1}\right) \bar{B}\left(s^{t-1}\right)+\text { Imports }- \text { Exports },
\end{gathered}
$$

that is, firms produce a homogenous good, $Y\left(s^{t}\right)$ through the technology described in equation (17). To do that, they need to hire labor, $H\left(s^{t}\right)$, and capital, $K\left(s^{t-1}\right)$.

Equation (19) is the Home country Current Account. It reflects the evolution of the nominal bonds, $\bar{B}\left(s^{t}\right)$, a firm buys (sells) depending on current imports being higher (lower) than current exports, and on the amount of past bonds held, $\bar{B}\left(s^{t-1}\right)$, all in terms of the domestic currency. This equation will be spelled out further when I discuss distribution costs. The term $e\left(s^{t}\right)$ denotes the nominal exchange rate (units of Home currency per unit of Foreign currency). ${ }^{8}$

Firms discount future profits by the relative marginal utility of the household, $\Lambda\left(s^{t+1}\right)$, with

$$
\Lambda\left(s^{t+1}\right)=\beta^{t+1} \frac{U_{c}\left(s^{t+1}\right)}{\bar{P}\left(s^{t+1}\right)} .
$$

The optimal conditions for labor, capital and bonds demands are

$$
\begin{gathered}
\frac{\bar{W}\left(s^{t}\right)}{\bar{P}_{H}\left(s^{t}\right)}=\frac{\alpha_{h} Y\left(s^{t}\right)}{R^{L}\left(s^{t}\right) H\left(s^{t}\right)}, \\
\frac{\bar{Q}\left(s^{t}\right)}{\bar{P}_{H}\left(s^{t}\right)}=\frac{\alpha_{k} Y\left(s^{t}\right)}{K\left(s^{t-1}\right)}, \\
E\left[\frac{U_{c}\left(s^{t+1}\right)}{\bar{P}\left(s^{t+1}\right)} \mid s^{t}\right]=\beta R^{B}\left(s^{t}\right) E\left[\frac{U_{c}\left(s^{t+2}\right)}{\bar{P}\left(s^{t+2}\right)} \mid s^{t}\right] .
\end{gathered}
$$

\subsection{Distribution costs}

In this model, I introduce distribution costs associated with the imported good in each country. I will consider two types of distribution costs.

The first type is the so-called iceberg cost and refers to the case when part of the exporting country's production is dedicated to transport. The second type of distribution costs covers the case in which part of the importing country's production is dedicated to transport. I will refer to this last type of cost as delivery costs. In both cases introducing these costs means that at Home the price at which producers export consumption goods $\left(\bar{P}_{H}\right)$ will not be the same as the price at which Foreign consumers import the same good $\left(\bar{P}_{H}^{*}\right)$. The difference is that some distribution costs must be paid to consume the imported good. These distribution costs are represented by the fraction $\phi$. This real friction means that absolute purchasing power parity

\footnotetext{
${ }^{8}$ Denoted in this way a depreciation of the Home currency means a increase of $e\left(s^{t}\right)$, and viceversa.
} 
need not always hold, in spite of the fact that prices are perfectly flexible. ${ }^{9}$ Let $q\left(s^{t}\right)$ be the real exchange rate defined as

$$
q\left(s^{t}\right)=\frac{e\left(s^{t}\right) \bar{P}^{*}\left(s^{t}\right)}{\bar{P}\left(s^{t}\right)}
$$

then with distribution costs $q\left(s^{t}\right)$ need not equal 1. In principle, both ways of introducing distribution costs drive a wedge between prices indices in both countries making it possible for a model with flexible prices to depart from the law of one price. But as I show below, these formulations of transport costs yield different results in the dynamics of exchange rates and the current account.

\subsubsection{Absence of distribution costs}

Consider first the case in which there are no distribution costs of importing/exporting goods $(\phi=0)$. Then we have

$$
\bar{P}_{F}\left(s^{t}\right)=e\left(s^{t}\right) \bar{P}_{F}^{*}\left(s^{t}\right),
$$

and

$$
\bar{P}_{H}^{*}\left(s^{t}\right)=\frac{\bar{P}_{H}\left(s^{t}\right)}{e\left(s^{t}\right)}
$$

that is, the law of one price holds for each of these goods.

However, since each country has different preferences over the goods $\left(\gamma<\frac{1}{2}\right.$ for home bias), the real price of consumption will differ in general between the two countries. The consumer price indices in the two countries are

$$
\bar{P}\left(s^{t}\right)=\kappa \bar{P}_{H}^{1-\gamma}\left(s^{t}\right) \bar{P}_{F}^{\gamma}\left(s^{t}\right),
$$

and

$$
\bar{P}^{*}\left(s^{t}\right)=\kappa\left(\bar{P}_{F}^{*}\left(s^{t}\right)\right)^{1-\gamma}\left(\bar{P}_{H}^{*}\left(s^{t}\right)\right)^{\gamma}=\kappa\left[\frac{\bar{P}_{F}\left(s^{t}\right)}{e\left(s^{t}\right)}\right]^{1-\gamma}\left[\frac{\bar{P}_{H}\left(s^{t}\right)}{e\left(s^{t}\right)}\right]^{\gamma}=\frac{\kappa}{e\left(s^{t}\right)}\left[\bar{P}_{F}\left(s^{t}\right)\right]^{1-\gamma}\left[\bar{P}_{H}\left(s^{t}\right)\right]^{\gamma} .
$$

It can be seen from these formulas that absolute purchasing power parity will hold, that is $\bar{P}\left(s^{t}\right)=e\left(s^{t}\right) \bar{P}^{*}\left(s^{t}\right)$ and therefore $q\left(s^{t}\right)=1$, in all states $s^{t}$, if and only if $\gamma=\frac{1}{2}$. (This is the case in which there is no bias for or against home goods, making preferences in the two countries symmetric.) Therefore, absolute PPP does not hold at all times even with flexible prices and costless transport. However, empirical research rejects the hypothesis of the absolute PPP. Thus, it may be more interesting to analyze the relative version of the PPP.

\footnotetext{
${ }^{9}$ Many models assume that the law of one price holds for traded goods. In the data it is not entirely true, but the prices of tradeables do converge faster than those of nontradeables, in 12 to 14 months (Walsh, 2003). In this model I am not distinguishing between tradables and nontradables, but between two homogeneous goods that are consumed in both countries, entering the utility function as imperfect substitutes.
} 
In a flexible price setting, prices react immediately to any shock, and if this happens in both countries such reaction may offset any movement in the real exchange rate. In order to prevent such an offset from happening I recur to distribution costs.

\subsubsection{Iceberg costs}

In the case of iceberg costs, prices at Home and Foreign countries differ in the following way:

$$
\bar{P}_{F}\left(s^{t}\right)=e\left(s^{t}\right) \bar{P}_{F}^{*}\left(s^{t}\right)(1+\phi)
$$

and

$$
\bar{P}_{H}^{*}\left(s^{t}\right)=(1+\phi) \frac{\bar{P}_{H}\left(s^{t}\right)}{e\left(s^{t}\right)} .
$$

That is, the price of the Foreign good imported at Home $\left(\bar{P}_{F}\left(s^{t}\right)\right)$ will not be the same as the price of the same good at the producing country, but will exceed this one by a fraction $\phi$, reflecting the extra amount I have to buy in order to consume $C_{F}\left(s^{t}\right)$, since the part $\phi$ is lost during the transportation. The same happens in the Foreign country for $\bar{P}_{H}^{*}\left(s^{t}\right)$.

In this case, the current account (equation (19)) is

$$
\bar{B}\left(s^{t}\right)=R^{B}\left(s^{t-1}\right) \bar{B}\left(s^{t-1}\right)+\bar{P}_{F}\left(s^{t}\right) C_{F}\left(s^{t}\right)-\bar{P}_{H}\left(s^{t}\right) C_{H}^{*}\left(s^{t}\right)(1+\phi),
$$

that is,

$$
\bar{B}\left(s^{t}\right)=R^{B}\left(s^{t-1}\right) \bar{B}\left(s^{t-1}\right)+(1+\phi)\left[e\left(s^{t}\right) \bar{P}_{F}^{*}\left(s^{t}\right) C_{F}\left(s^{t}\right)-\bar{P}_{H}\left(s^{t}\right) C_{H}^{*}\left(s^{t}\right)\right] .
$$

From this second version of the equation, it can be seen that each country's exports must be paid the full price of the goods ship, including the part which will be lost in transport.

\subsubsection{Delivery costs}

For Home firms who import $C_{F}\left(s^{t}\right)$ this means that they will pay

$$
\bar{P}_{F}\left(s^{t}\right)=e\left(s^{t}\right) \bar{P}_{F}^{*}\left(s^{t}\right)+\phi \bar{P}_{H}\left(s^{t}\right),
$$

reflecting expenditure of Home goods to import the Foreign good (due, for example, to transport costs or services necessary to bring the foreign good to the Home country). These extra costs are a fixed fraction, $\phi$, of the Home good, and must be paid in domestic goods costing $\bar{P}_{H}\left(s^{t}\right)$.

A symmetric assumption will hold for the Foreign country, which imports $C_{H}^{*}\left(s^{t}\right)$ units of the Home produced good. In this case

$$
\bar{P}_{H}^{*}\left(s^{t}\right)=\frac{\bar{P}_{H}\left(s^{t}\right)}{e\left(s^{t}\right)}+\phi \bar{P}_{F}^{*}\left(s^{t}\right)
$$


in units of the foreign currency. For simplicity, I will assume that the degree of distribution costs, $\phi$, is the same across countries.

Under delivery costs, the current account (equation (19)) is

$$
\bar{B}\left(s^{t}\right)=R^{B}\left(s^{t-1}\right) \bar{B}\left(s^{t-1}\right)+e_{t} \bar{P}_{F}^{*}\left(s^{t}\right) C_{F}\left(s^{t}\right)-\bar{P}_{H}\left(s^{t}\right) C_{H}^{*}\left(s^{t}\right) .
$$

Here it can be seen that exporter earnings do not include transport costs. Transport costs have no effect on the current account since they are paid inside the exporting country.

\subsubsection{Differences between the distribution costs}

Consider the linearized version of the price equations

$$
\begin{aligned}
& \hat{p}_{t}=(1-\gamma) \hat{p}_{H t}+\gamma \hat{p}_{F t}, \\
& \hat{p}_{t}^{*}=(1-\gamma) \hat{p}_{F t}^{*}+\gamma \hat{p}_{H t}^{*} .
\end{aligned}
$$

In the case of iceberg costs we have

$$
\begin{aligned}
& \hat{p}_{F t}=\hat{e}_{t}+\hat{p}_{F t}^{*}, \\
& \hat{p}_{H t}^{*}=\hat{p}_{H t}-\hat{e}_{t},
\end{aligned}
$$

which implies CPIs as follows:

$$
\hat{p}_{t}=(1-\gamma) \hat{p}_{H t}+\gamma \hat{e}_{t}+\gamma \hat{p}_{F t}^{*},
$$

and

$$
\hat{p}_{t}^{*}=(1-\gamma) \hat{p}_{F t}^{*}+\gamma \hat{p}_{H t}-\gamma \hat{e}_{t} .
$$

In this case, the real exchange rate will be (after some algebra)

$$
\hat{q}_{t}=\hat{e}_{t}+\hat{p}_{t}^{*}-\hat{p}_{t}=(1-2 \gamma)\left(\hat{e}_{t}+\hat{p}_{F t}^{*}-\hat{p}_{H t}\right) .
$$

Notice that the parameter reflecting distribution costs does not appear in the evolution of the real exchange rate!

Consider now the case of delivery costs. In this case we have

$$
\begin{gathered}
\hat{p}_{F t}=\frac{e P_{F}^{*}}{P_{F}}\left(\hat{e}_{t}+\hat{p}_{F t}^{*}\right)+\frac{\phi P_{H}}{P_{F}} \hat{p}_{H t}, \\
\hat{p}_{H t}^{*}=\frac{P_{H}}{e P_{H}^{*}} \hat{p}_{H t}+\left[\frac{\phi P_{F}^{*}}{P_{H}^{*}}-1\right] \hat{e}_{t}+\frac{\phi P_{F}^{*}}{P_{H}^{*}} \hat{p}_{F t}^{*},
\end{gathered}
$$


implying CPIs as follows:

$$
\hat{p}_{t}=\left[1-\gamma+\frac{\gamma \phi P_{H}}{P_{F}}\right] \hat{p}_{H t}+\gamma \frac{e P_{F}^{*}}{P_{F}}\left(\hat{e}_{t}+\hat{p}_{F t}^{*}\right),
$$

and

$$
\hat{p}_{t}^{*}=\left[1-\gamma+\frac{\gamma \phi P_{F}^{*}}{P_{H}^{*}}\right] \hat{p}_{F t}^{*}+\frac{\gamma P_{H}}{e P_{H}^{*}} \hat{p}_{H t}+\gamma\left[\frac{\phi P_{F}^{*}}{P_{H}^{*}}-1\right] \hat{e}_{t} .
$$

In this case, the real exchange rate will be (after some algebra)

$$
\hat{q}_{t}=\hat{e}_{t}+\hat{p}_{t}^{*}-\hat{p}_{t}=\left[1-\gamma+\frac{\gamma \phi P_{F}^{*}}{P_{H}^{*}}-\gamma \frac{e P_{F}^{*}}{P_{F}}\right]\left(\hat{e}_{t}+\hat{p}_{F t}^{*}\right)-\left[1-\gamma+\frac{\gamma \phi P_{H}}{P_{F}}-\frac{\gamma P_{H}}{e P_{H}^{*}} p_{H t}\right] \hat{p}_{H t} .
$$

Unlike the previous case, here the degree of distribution costs does affect the dynamics of the real exchange rate.

In the simulations below I consider both cases of distribution costs and analyze the differences they induce in the dynamics across countries.

\subsection{Financial intermediaries}

Banks have the role of taking funds from those who have resources to lend, and making them available to agents in need of funding. In this case, the representative Home bank will collect deposits from Home households, $\bar{D}\left(s^{t-1}\right)$, and together with the monetary injection of the Home central bank, $\bar{X}\left(s^{t}\right)$, will transform these funds into loans to firms every period, $\bar{L}\left(s^{t}\right)$.

At the end of the period, the financial intermediary receives principal plus interest on the loans from firms, additionally, it has to pay back principal plus interests due on households' deposits, $R^{D}\left(s^{t}\right) \bar{D}\left(s^{t-1}\right)$. These profits are then distributed to households, who own the banks, at the end of the period, as is seen from equation (5),

$$
\bar{\Pi}_{t}^{F I}=R\left(s^{t}\right) \bar{X}\left(s^{t}\right) .
$$

\subsection{The fiscal authority}

There is a government in this economy which consumes an amount $G_{t}$. This government spending is financed by lump sum taxes levied from households, $T_{t}$. In this economy government spending is random and fluctuates according to

$$
G_{t}=G_{t-1}^{\rho_{g}} \exp \left(\varepsilon_{g, t}\right)
$$

with $0<\rho_{g}<1$, and $\varepsilon_{g, t}$ is an i.i.d. normal shock with zero mean and standard deviation $\sigma_{g}^{\varepsilon}$.

It is assumed that in each country, the fiscal authority maintains a balanced budget every period, that is,

$$
G_{t}=T_{t}, \text { for } \forall t .
$$




\subsection{The central bank}

The central bank in this model is in charge of conducting monetary policy. It issues money directly to financial intermediaries at an exogenously given rate $\mu_{t}$ that follows an $\mathrm{AR}(1)$ process, with autocorrelation coefficient $\rho_{\mu} \in(0,1)$. According to this, the new injection of money each period is

$$
\bar{X}\left(s^{t}\right)=\mu_{t} \bar{M}\left(s^{t-1}\right),
$$

so that the total amount of money at the end of period $t$ and beginning of $t+1$ will be

$$
\bar{M}\left(s^{t}\right)=\bar{M}\left(s^{t-1}\right)+\bar{X}\left(s^{t}\right) .
$$

\section{Equilibrium conditions}

A competitive equilibrium in this economy is a set of functions, and a set of variables such that for each country and given the state of the economy $s_{t}=\left(K_{t}, B_{t}, K_{t}^{*}, B_{t}^{*}, A_{t}, X_{t}, A_{t}^{*}, X_{t}^{*}\right)$, the following needs to hold:

i) households' problem is solved, that is, utility is maximized (1), subject to (2)-(6);

ii) firms' problem is solved, that is, profits are maximized (15), subject to (16)-(19);

iii) banks behave in a competitive way;

iv) there is no arbitrage in credit markets, that is,

$$
\begin{gathered}
R^{D}\left(s^{t}\right)=R^{\mathcal{L}}\left(s^{t}\right)=R\left(s^{t}\right) \\
R^{D *}\left(s^{t}\right)=R^{\mathcal{L} *}\left(s^{t}\right)=R^{*}\left(s^{t}\right)
\end{gathered}
$$

v) and finally markets clear, that is,

$$
\begin{gathered}
H\left(s^{t}\right)=N\left(s^{t}\right), \\
H^{*}\left(s^{t}\right)=N^{*}\left(s^{t}\right), \\
\bar{D}\left(s^{t}\right)+\bar{X}_{t}=\bar{W}\left(s^{t}\right) H\left(s^{t}\right), \\
\bar{D}^{*}\left(s^{t}\right)+\bar{X}_{t}^{*}=\bar{W}^{*}\left(s^{t}\right) H^{*}\left(s^{t}\right), \\
Y\left(s^{t}\right)=C_{H}\left(s^{t}\right)+C_{H}^{*}\left(s^{t}\right)+\phi C_{F}\left(s^{t}\right)+Z\left(s^{t}\right)+G_{t}, \\
Y^{*}\left(s^{t}\right)=C_{F}^{*}\left(s^{t}\right)+C_{F}\left(s^{t}\right)+\phi C_{H}^{*}\left(s^{t}\right)+Z^{*}\left(s^{t}\right)+G_{t}^{*}, \\
\bar{B}\left(s^{t}\right)=R^{B}\left(s^{t-1}\right) \bar{B}\left(s^{t-1}\right)+e_{t} \bar{P}_{F}^{*}\left(s^{t}\right) C_{F}\left(s^{t}\right)-\bar{P}_{H}\left(s^{t}\right) C_{H}^{*}\left(s^{t}\right), \\
\bar{B}^{*}\left(s^{t}\right)=R^{B *}\left(s^{t-1}\right) \bar{B}^{*}\left(s^{t-1}\right)+\frac{\bar{P}_{H}\left(s^{t}\right)}{e\left(s^{t}\right)} C_{H}^{*}\left(s^{t}\right)-\bar{P}_{F}^{*}\left(s^{t}\right) C_{F}\left(s^{t}\right),
\end{gathered}
$$


for delivery costs or

$$
\begin{gathered}
Y\left(s^{t}\right)=C_{H}\left(s^{t}\right)+C_{H}^{*}\left(s^{t}\right)(1+\phi)+Z\left(s^{t}\right)+G_{t}, \\
Y^{*}\left(s^{t}\right)=C_{F}^{*}\left(s^{t}\right)+C_{F}\left(s^{t}\right)(1+\phi)+Z^{*}\left(s^{t}\right)+G_{t}^{*}, \\
\bar{B}\left(s^{t}\right)=R^{B}\left(s^{t-1}\right) \bar{B}\left(s^{t-1}\right)+\bar{P}_{F}\left(s^{t}\right) C_{F}\left(s^{t}\right)-\bar{P}_{H}\left(s^{t}\right) C_{H}^{*}\left(s^{t}\right)(1+\phi), \\
\bar{B}^{*}\left(s^{t}\right)=R^{B *}\left(s^{t-1}\right) \bar{B}^{*}\left(s^{t-1}\right)+\bar{P}_{H}^{*}\left(s^{t}\right) C_{H}^{*}\left(s^{t}\right)-\bar{P}_{F}^{*}\left(s^{t}\right) C_{F}\left(s^{t}\right)(1+\phi),
\end{gathered}
$$

for iceberg costs

$$
\begin{gathered}
G_{t}=T_{t}, \\
G_{t}^{*}=T_{t}^{*}, \\
\bar{B}\left(s^{t}\right)+e\left(s^{t}\right) \bar{B}^{*}\left(s^{t}\right)=0 .
\end{gathered}
$$

\section{Calibration}

The model is solved by log-linearizing around the nonstochastic steady state with zero initial nominal bonds. Therefore both countries are symmetric, greatly reducing the dimension of the problem, and I will only specify the parameters for the Home country. The calibration intends to match certain stylized facts in US and European data. The time period is a quarter. The data are mean values for US over the period 1980:1-2001:2 obtained from OECD Main Economic Indicators.

Preferences: $\beta=0.9945$, matching a annual nominal interest rate of $7.4 \%$ (US mean of FFR) given a quarterly growth rate of M1 equal to $1.6 \%$; intertemporal elasticity of substitution $\theta=1$, and inverse of labor supply elasticity with respect to wages $\psi=0.7$, both parameters are consistent with other studies as mentioned by Chari et al. (1999) and with separable preferences over consumption and leisure imply a larger volatility for exchange rates. I set $\gamma=0.15$, a degree of openness implying a ratio of imports over output equal to $10.4 \%$ (consistent with the USAEurope case).

Technology: capital's share of output $\alpha=0.36$; due to constant returns to scale assumption labor's share of output is $1-\alpha=0.64$; the rate of depreciation is $\delta=10 \%$ annually, meaning a ratio of capital over output of 10.77 ; distribution costs $\phi=3.8 \%$ meaning a distribution margin equal to $3.7 \%$ consistent with measures by Hummels (1999) for the US.

Exogenous shocks: the parameters governing the technology and money growth processes for both countries are estimated from data for the US and an aggregate of European countries. Regarding technology shocks, I follow the procedure employed by Backus, Kehoe and Kydland (1992) and use the data in Chari, Kehoe and McGrattan (2001) to estimate the Solow residuals 
for the US (Home) and Europe (Foreign). The sample goes from 1972.1 to 1994:4. The estimates of the bivariate process have the following estimated autocorrelation matrix:

$$
\left[\begin{array}{cc}
\rho_{a} & \rho_{a a^{*}} \\
\rho_{a^{*} a} & \rho_{a^{*}}
\end{array}\right]=\left[\begin{array}{cc}
0.9916 & 0.0122 \\
(0.0136) & (0.0154) \\
0.0286 & 0.9776 \\
(0.0136) & (0.0153)
\end{array}\right] .
$$

The variance covariance matrix for the innovations is

$$
\Sigma_{a}=\left[\begin{array}{cc}
\sigma_{a} & \sigma_{a a^{*}} \\
\sigma_{a^{*} a} & \sigma_{a^{*}}
\end{array}\right]=\left[\begin{array}{cc}
0.0066 & 0.000015 \\
0.000015 & 0.0075
\end{array}\right] .
$$

However, to impose symmetry across countries I calculate the symmetric matrix whose eigenvalues are the same as the estimated matrix. This matrix is

$$
\left[\begin{array}{cc}
\rho_{a} & \rho_{a a^{*}} \\
\rho_{a^{*} a} & \rho_{a^{*}}
\end{array}\right]=\left[\begin{array}{cc}
0.9846 & 0.0189 \\
0.0189 & 0.9846
\end{array}\right],
$$

with 0.0071 and 0.2953 as standard deviation and correlations, respectively, for the technology innovations.

Regarding money growth processes I proceed in the same way as before. The data now are M1 and obtained from the OECD and correspond to the US and an aggregate of European countries for the period 1980:1-2003:2. The matrix of autocorrelation coefficients is

$$
\left[\begin{array}{cc}
\rho_{\mu} & \rho_{\mu \mu^{*}} \\
\rho_{\mu^{*} \mu} & \rho_{\mu^{*}}
\end{array}\right]=\left[\begin{array}{cc}
0.5839 & -0.2575 \\
(0.1544) & (0.2054) \\
-0.0172 & 0.1381 \\
(0.0696) & (0.1217)
\end{array}\right],
$$

and for the innovations

$$
\Sigma_{\mu}=\left[\begin{array}{cc}
\sigma_{\mu} & \sigma_{\mu \mu^{*}} \\
\sigma_{\mu^{*} \mu} & \sigma_{\mu^{*}}
\end{array}\right]=\left[\begin{array}{cc}
0.0092 & -0.0006 \\
-0.0006 & 0.0055
\end{array}\right] .
$$

Again imposing symmetry across countries, the matrix used in the simulations is

$$
\left[\begin{array}{cc}
\rho_{\mu} & \rho_{\mu \mu^{*}} \\
\rho_{\mu^{*} \mu} & \rho_{\mu^{*}}
\end{array}\right]=\left[\begin{array}{cc}
0.3611 & -0.1222 \\
-0.1222 & 0.3611
\end{array}\right],
$$

with 0.0074 and 0.08 as standard deviation and correlations, respectively, for the monetary innovations.

Finally, the autocorrelation of government shocks $\left(\rho_{g}\right)$ is set to 0.95 , and the standard deviation is $\sigma_{g}^{\varepsilon}=0.004$. It is assumed that government shocks are not correlated across countries. 


\section{Findings}

This section analyzes the response of the economy to different sources of disturbances. In particular, I study the transmission of productivity, money supply and government spending shocks and the business cycle properties of the model under alternative structures of distribution costs. The aim is to find the structure that helps the model generate business cycle properties as close as possible to those found in the data. First, I report the impulse response functions corresponding to the model with iceberg costs. Below, I compare the dynamics with iceberg and with delivery costs. In all the figures, I plot variables as percentage deviations from their steady state values, except for net exports that are as percentage of nominal Home GDP, and nominal interest rates that are as percentage points.

\subsection{Productivity shocks}

Figure 4 reports the impulse response functions of Home and Foreign countries to a one standard deviation improvement in productivity originating at Home at time $t=2$. In the figures, the dash-circled line represents the Home country and the dash-crossed line stands for the Foreign country. The solid line is used for exchange rates and net exports.

The model considered reports similar impulse response functions to those in the literature on international real business cycles (see for example Baxter and Crucini, 1994). After a rise in the Home productivity, home output, labor, consumption and investment increase; in the foreign country, consumption rises while investment and labor fall on impact and then rise gradually together with output.

Consumption increases in both countries, jumping up quickly at Home while increasing slowly in Foreign, as both countries substitute towards the cheaper Home good. Notice that the sign of net exports (exports minus imports in the Home country) becomes negative. The reason is that even though the consumption of the Home good by Foreign consumers $\left(C_{H}^{*}\right)$ rises, the higher total consumption at Home means consumption of the foreign good at Home $\left(C_{F}\right)$ remains high. The worsening of the terms of trade for the Home country is thus sufficient to make net exports fall.

Furthermore, the model allows for the study of the reaction of both nominal and real exchange rates as well as prices. After the shock, the nominal exchange rate is almost exactly unchanged, while there is a substantial real depreciation. In other words, the greater abundance of Home goods after the positive technology shock makes these goods cheaper, reflected by the real depreciation, the fall in the Home consumption price index. At the same time interest rates at Home rise because of the increased demand for money from both firms and households to hire 
more workers and consume more, respectively, while falling in the Foreign country.

\subsection{Money supply shocks}

Studying money supply shocks is an important challenge for limited participation models in an open economy context. Previous monetary analysis with limited participation models has failed to replicate some of the stylized facts in international business cycle data. Below I show that this flexible price two-country model is able to replicate a liquidity effect and both nominal and real depreciations after a positive money injection.

Figure 5 shows the impulse response functions of the model to a 1 standard deviation monetary innovation at time $t=2$. As in the previous section, the dash-circled line refers to the Home country and the dash-crossed line to the Foreign country in all panels except for exchange rates and net exports.

After a money injection at Home, both Home output, consumption and labor increase. There is a small lagged rise in the Foreign consumption, whereas both Home and Foreign investment fall. ${ }^{10}$ The price index rises at Home, and there is a small, lagged fall in foreign prices. As in the data, nominal interest rates fall in both countries but more at Home (where the shock originated) and there are both a nominal and a real depreciation for the Home country. The current account goes into deficit for the Home country, because of the rising in home consumption.

The first important result here is that the model generates a liquidity effect at Home and at Foreign, as in the data. In this sense, this framework improves upon previous limited participation models that had difficulties in generating such effect. For example, Schlagenhauf and Wrase (1995) find that extra rigidities are needed, like sluggish capital, to generate the fall in interest rate after a money injection.

The mechanism at work is the same that in closed-economy limited participation models. The excess money supply can only be absorbed by firms, since households cannot change their deposit decisions until the following period. Recall that after a monetary injection there are two effects at work that go in opposite directions: an anticipated inflation effect due to the excess of money in the economy, and a liquidity effect, that is a fall in the nominal interest rate also due to the extra money injected. Higher inflation means higher nominal interest rates, whereas the liquidity effect drives the nominal interest rate down. The higher the autocorrelation of the money supply shock, the more dominant the anticipated inflation effect. In a flexible price

\footnotetext{
${ }^{10}$ This negative correlation between consumption and investment may be due to consumption being a cash good and investment a credit good, so that the anticipated inflation effect acts much more strongly on consumption. An alternative version of this model in which both are cash goods (and therefore subject to the inflation tax) is left for future research.
} 
model, prices react immediately to the shock and therefore the anticipated inflation effect is high, sometimes offsetting the liquidity effect. This is not the case in this model, where prices rise in response to the shock but the nominal interest rate falls, reflecting a liquidity effect. Firms will only clear the money market if the interest rate is lower, so the Home nominal interest rate falls. At Foreign, the lagged transmission of the money supply shock plus the fall in money demand by firms reduces the domestic nominal interest rate.

Moreover, the second point to remark is that this liquidity effect does not only last for one period, a fact that has been criticized to most limited participation models, but it lasts for at least three quarters at Home and slightly less at Foreign.

Finally, in the model as in the data, the liquidity effect is larger in Home than in Foreign, and thus the international interest rate spread increases after the shock. At the same time the nominal exchange rate depreciates. However, the strong response of Home prices to the domestic shock together with the weaker response of Foreign prices, prevents the model from showing a stronger real depreciation like that observed in the data.

\subsection{Government shocks}

Figure 6 plots the impulse response functions of the model to a $1 \%$ government spending shock at time $t=2$. As in the previous section, the solid line refers to the Home country and the dashed line to the Foreign country in all panels except for exchange rates and net exports.

The increase in government spending is paid for by a rise in lump sum taxes. Output rises in response to the shock, while government spending crowds out both investment and consumption. The crowding out effect on consumption is also transmitted to the Foreign country. Although the shock is temporary, it is highly persistent $\left(\rho_{g}=0.95\right)$ and thus induces both a substitution and wealth effect on the household's decisions. Because of this wealth effect, and because the nominal interest rate rises at Home, making it more profitable to work, labor rises too. Nonetheless, the rise in demand is sufficient to make prices rise at Home, making it more expensive to consume the Home good for both Home and Foreign households.

Finally, this rise in demand for Home goods induces a real appreciation of the Home currency (a fall in the real exchange rate), while having almost no effect on the nominal exchange rate. For the same reason, the trade balance turns negative.

\subsection{Iceberg versus delivery costs}

Finally, it is helpful to analyze in detail the differences observed depending on the type of transport costs introduced. Figures 7 to 9 compare the reaction of some of the variables to each 
shock analyzed under iceberg and delivery costs. Unsurprisingly, the main differences arise in exchange rates and net exports.

Recall the differences in prices under the alternative structures given by equations (29) to (34). For iceberg costs the equations are

$$
\begin{gathered}
\bar{P}_{F}\left(s^{t}\right)=e\left(s^{t}\right) \bar{P}_{F}^{*}\left(s^{t}\right)(1+\phi), \\
\bar{P}_{H}^{*}\left(s^{t}\right)=(1+\phi) \frac{\bar{P}_{H}\left(s^{t}\right)}{e\left(s^{t}\right)}
\end{gathered}
$$

and for delivery costs

$$
\begin{gathered}
\bar{P}_{F}\left(s^{t}\right)=e\left(s^{t}\right) \bar{P}_{F}^{*}\left(s^{t}\right)+\phi \bar{P}_{H}\left(s^{t}\right), \\
\bar{P}_{H}^{*}\left(s^{t}\right)=\frac{\bar{P}_{H}\left(s^{t}\right)}{e\left(s^{t}\right)}+\phi \bar{P}_{F}^{*}\left(s^{t}\right) .
\end{gathered}
$$

Changes in domestic prices affect the cost of both exports and imports if there are delivery costs, whereas have a stronger effect on the price of exports under iceberg costs. Therefore, if the Home consumption good is more expensive the switching expenditure effect is weaker under delivery costs, because rising domestic prices also increase the price of imports. However, under iceberg costs such effect is stronger and reflected in net exports.

Real shocks that mean a change in the efficiency of producing goods affect mainly exchange rates if there are delivery costs, whereas if trade costs are iceberg the main effects are captured by changes in net exports. On the other hand, nominal shocks do not reflect differences in efficiency, therefore affect overall consumption in the same direction, and basically induce appreciations or depreciations of the exchange rates that absorb the effects of the shocks under both costs structures.

In particular the nominal exchange rate reacts more to productivity and fiscal shocks. Notice that in general, the magnitude of the reaction for the real exchange rate is smaller under delivery costs than iceberg costs. The reason is that modelling prices with delivery costs combines the dynamics at Home and Foreign in the determination of $\bar{P}_{F}$ and $\bar{P}_{H}^{*}$. This is not the case under iceberg costs where the dynamics of $\bar{P}_{F}$ and $\bar{P}_{H}^{*}$ only depend on the other country's price and the nominal exchange rate. Notice however that for the same reason, in the case of a money injection, it is the iceberg costs model the one that generates both a nominal and a real depreciation of the domestic country, whereas the model with delivery costs induces no real depreciation.

\section{Simulation results}

In what follows I will study the business cycle properties of the model economy and compare them with the data. I also discuss the differences caused by the introduction of distribution costs in different ways. 
Tables 2 and 3 report the moments generated by the model according to the parameterization in Section 5. Table 2 shows first standard deviations of output, labor, consumption, investment, prices, nominal and real exchange rates for the US and Europe. It also reports a set of correlations and autocorrelations for some of these variables. Below, Table 3 shows cross-country correlations. For all the moments displayed, I show those implied by the standard limited participation model without distribution costs, for the model with iceberg costs and the case with delivery costs.

In all three cases, as in the data, investment and the nominal exchange rate are especially volatile variables, while consumption and labor are less so. In particular, all the three models report much lower labor volatility than the observed in the data. Also nominal and real exchange rates are insufficiently volatile.

Regarding correlations, the model reports the high procyclicality of consumption, labor and investment observed in the data. In the model, the real exchange rate and output are positively correlated contrary to what appears in the data analyzed in Section 2. However, in line with Kollmann (2001) there is no clear pattern on the cyclicality of the nominal exchange rate that is almost acyclical in the model. Real and nominal exchange rates fail to report the high correlation of the data. This correlation is even negative in the case of no distribution costs and with iceberg costs and only slightly positive under delivery costs. The table also shows strong positive autocorrelation for output and the real exchange rate, consistent with the empirical evidence, but lower persistence of the nominal exchange rate than in the data. Without crosscountry spillovers shocks originating at Home are not transmitted as strongly to the Foreign country. Therefore, the real exchange rate depends mainly on domestic dynamics and this is reflected in a higher correlation with domestic output. Moreover, the offsetting effects induced by foreign dynamics disappear and increase the volatility and persistence of $q$. Finally, as appears in Table 3, the model reports the output-consumption puzzle generated by most business cycle models, that is higher cross-country correlation of consumption than output.

It is worth pointing out, that the inclusion of distribution costs, in either way (iceberg or delivery) does not affect the business cycles properties reported in tables 2 and 3. However, the simulated impulse response functions do show differences conditional on individual shocks as shown by Figures 7 to 9 . In particular, in this limited participation model, domestic money injections generate both nominal and real depreciations of the domestic currency if there are iceberg costs in trade, whereas there is no real depreciations under delivery costs. The strength of the expenditure switching effect also differs across trade costs structures.

It can be the case that in the aggregation of all shocks and once international spillovers are considered some of the effects may cancel out and lead to the moments reported in tables 2 and 
3. To check this, Table 4 reports the simulated moments conditional on productivity, money supply and fiscal shocks separately for the two distribution cost models and for the case of no distribution costs. In all cases, there are cross-country spillovers. Now, differences arise.

When cross-country spillovers are taken into account, productivity shocks explain most of the dynamics of the variables considered, mainly with delivery costs, except for the volatility of nominal exchange rates that appear to be merely a monetary phenomenon. One possible explanation is that delivery costs become relevant when there are shocks to productivity. Technology shocks affect relative prices at Home, that is now more productive, with respect to the Foreign good. This changes relative demands of goods and is reflected in the dynamics of the real exchange rate. However notice that only the model with delivery costs reports procyclicality of the nominal exchange rate and the high correlation of exchange rates as in the data. If there are iceberg costs, higher productivity at Home makes domestic goods less expensive to both domestic and foreign consumers. Demand for the domestic good increases in both countries leading to an appreciation of the domestic currency, this explains the countercyclicality of the nominal exchange rate. Under delivery costs although domestic goods are less expensive to both consumers, it is still expensive for Foreign consumers to import the Home good since they need to devote Foreign goods to "deliver" the imported good. This induces a depreciation of the domestic currency and procyclicality.

Money supply shocks affect mainly prices, without any correspondence on productivities nor therefore on efficiency. Changes in relative prices will affect relative demands and therefore will induce movements in nominal exchange rates subject to changes in demand. This is reflected in the higher volatility and procyclicality of the nominal exchange rate.

Finally, fiscal shocks account for little of the volatility of output and exchange rates. However, they do introduce high persistence and correlation of exchange rates due to its high autocorrelation $\left(\rho_{g}=0.95\right)$, even though there is no difference between the type of distribution costs introduced.

\section{Discussion of the results}

In general, the model presented here improves qualitatively upon Schlagenhauf and Wrase (1995) since it is able to replicate the dynamics of interest rates and exchange rates after a money injection with no rigidity other than the standard limited participation. More concretely, after a positive money supply shock domestic and foreign nominal interest rates fall, and the difference between them increases. At the same time, there is both a nominal and a real depreciation of the domestic currency. The nominal depreciation appears under the two structures of distribution 
costs considered while only iceberg costs report the real depreciation. This may be a result of the combination of transport costs with a new alternative framework for exchange rate determination, compared to other limited participation open economy models. In previous models, households held currency of the two countries and exchange rates were determined at the beginning of the period when individuals chose their money holdings of each currency. In contrast, in this model the exchange rate is determined during the period, when importing firms chose how many bonds to buy (sell), a decision that is determined by how much of the foreign good households want to consume. This new setup, closer to other open economy models, favours comparison among different setups and opens new channels for the transmission of shocks.

In addition, I introduce distribution costs to explain why purchasing power parity need not hold, as empirical evidence seems to say. Intuitively, transport costs seem more reasonable than sticky prices in explaining lack of equalization of prices of tradable goods, which are in principle more subject to competition and therefore, less likely to have sticky prices.

The main quantitative problem for the model is its failure to generate highly volatile exchange rates. This is a big pitfall for flexible price models and sticky price models too. ${ }^{11}$ Although distribution costs (mainly delivery) help increase the volatility of nominal exchange rates, they do not improve with respect to that of real exchange rates.

\section{Directions for future research}

This paper presents a two-country flexible price monetary model that allows for the study of international business cycles. The model is able to replicate the movements in the main economic variables, together with nominal interest and exchange rates. In attaining this I introduced distribution costs and an alternative setup for exchange rate determination in an otherwise standard monetary model. The results suggest a relevant role of distribution costs, mainly in the form of delivery costs versus iceberg costs, in helping the model fit the business cycle properties of exchange rates under certain structure of shocks. In particular, it shows a liquidity effect at Home, increased international interest rate spreads and both the nominal and real depreciation observed in the data after a monetary injection. This is an improvement upon previous open economy flexible price models. However, quantitatively, there is still room for improvement.

This paper is the starting point of a line of research that intends to analyze the international monetary transmission mechanism, with special emphasis on the role of financial frictions across countries. Therefore, the next step is to improve the quantitative fit of the model by allowing

\footnotetext{
${ }^{11}$ See Schlagenhauf and Wrase (1995) for a limited participation case and Chari, Kehoe and McGrattan (2001) for the sticky price case.
} 
for imperfect credit markets within each country and analyze first qualitatively the international transmission of shocks and then assess the quantitative performance of the model. This is left for future work. 


\section{References}

Backus, D.K., P. J. Kehoe and F. E. Kydland. 1992. "International Real Business Cycles." Journal of Political Economy, 100(4): 745-775.

Barth, M. J., III and V. A. Ramey. 2001. "The cost channel of monetary transmission." NBER Macroeconomics Annual 2001, Cambridge, MA. MIT Press: 199-239.

Baxter, M. 1995. "International Trade and Business Cycles." Handbook of International Economics, vol. 3, chapter 35 .

Baxter, M. and M.J. Crucini. 1994. "Business cycles and the asset structure of foreign trade." NBER Working Paper 4975, December.

Burnstein, A.; M. Eichenbaum, and S. Rebelo. 2002. "Why is inflation so low after large devaluations?" Mimeo.

Burnstein, A.; J. Neves, and S. Rebelo. 2003. "Distribution costs and real exchange rate dynamics during exchange-rate-based stabilizations." Journal of Monetary Economics, 50, 3: $1189-1214$.

Chari, V.V.; P.J. Kehoe, and E. R. McGrattan. 2001. "Can sticky price models generate volatile and persistent real exchange rates?", Federal Reserve Bank of Minneapolis Research Department Staff Report 223.

Christiano, L., and M. Eichenbaum (1992). "Liquidity effects and the monetary transmission mechanism" American Economic Review, 82, no. 2: 346-353.

Christiano, L., and M. Eichenbaum (1995). "Liquidity effects, monetary policy and the business cycles." Journal of Money, Credit, and Banking, 27(4), Part 1, November: 1113-1136.

Eichenbaum, M. and C. L. Evans. 1995. "Some empirical evidence on the effects of shocks to monetary policy on exchange rates." Quarterly Journal of Economics, 110(4), November: 975-1009.

Fuerst, T. S. (1992). "Liquidity, loanable funds, and real activity." Journal of Monetary Economics, 29: 3-24.

Hummels, D. 1999. "Toward a geography of trade costs." Mimeo.

Kollmann, R. 2001. "The exchange rate in a dynamic-optimizing business cycle with nominal rigidities: a quantitative investigation." Journal of International Economics, 55: 243-262.

Rauch, J. E. 1999. "Networks versus markets in international trade." Journal of International Economics, 48: 7-35.

Schlagenhauf, D. E., and J. M. Wrase. 1995. "Liquidity and real activity in a simple open economy model." Journal of Monetary Economics, 35: 431-461.

Walsh, C. E. 2003. "Monetary Theory and Policy." MIT Press, 2nd edition. 
Complete set of equations: iceberg costs model

\section{Contemporaneous equations}

$$
\begin{aligned}
& C\left(s^{t}\right)=C_{H}^{1-\gamma}\left(s^{t}\right) C_{F}^{\gamma}\left(s^{t}\right), \\
& C_{H}\left(s^{t}\right)=\left(\frac{1-\gamma}{\gamma}\right)^{\gamma}\left(\frac{\bar{P}_{H}\left(s^{t}\right)}{\bar{P}_{F}\left(s^{t}\right)}\right)^{-\gamma} C\left(s^{t}\right), \\
& C_{F}\left(s^{t}\right)=\left(\frac{\gamma}{1-\gamma}\right)^{1-\gamma}\left(\frac{\bar{P}_{F}\left(s^{t}\right)}{\bar{P}_{H}\left(s^{t}\right)}\right)^{-(1-\gamma)} C\left(s^{t}\right), \\
& \bar{M}\left(s^{t-1}\right)+\bar{X}_{t} \geq \bar{P}\left(s^{t}\right) C\left(s^{t}\right) . \\
& \bar{P}_{H}\left(s^{t}\right) C_{H}\left(s^{t}\right)+\bar{P}_{F}\left(s^{t}\right) C_{F}\left(s^{t}\right)=\bar{P}\left(s^{t}\right) C\left(s^{t}\right) \\
& \bar{P}_{H}\left(s^{t}\right) C_{H}\left(s^{t}\right)=(1-\gamma) \bar{P}\left(s^{t}\right) C\left(s^{t}\right) \\
& \bar{P}_{F}\left(s^{t}\right) C_{F}\left(s^{t}\right)=\gamma \bar{P}\left(s^{t}\right) C\left(s^{t}\right) \\
& \bar{P}_{F}\left(s^{t}\right)=\bar{e}\left(s^{t}\right) \bar{P}_{F}^{*}\left(s^{t}\right)(1+\phi) \\
& C^{*}\left(s^{t}\right)=C_{F}^{* 1-\gamma}\left(s^{t}\right) C_{H}^{* \gamma}\left(s^{t}\right) \\
& \bar{P}_{F}^{*}\left(s^{t}\right) C_{F}^{*}\left(s^{t}\right)=(1-\gamma) \bar{P}^{*}\left(s^{t}\right) C^{*}\left(s^{t}\right) \\
& \bar{P}_{H}^{*}\left(s^{t}\right) C_{H}^{*}\left(s^{t}\right)=\gamma \bar{P}^{*}\left(s^{t}\right) C^{*}\left(s^{t}\right) \\
& C_{F}^{*}\left(s^{t}\right)=\left(\frac{1-\gamma}{\gamma}\right)^{\gamma}\left(\frac{\bar{P}_{F}^{*}\left(s^{t}\right)}{\bar{P}_{H}^{*}\left(s^{t}\right)}\right)^{-\gamma} C^{*}\left(s^{t}\right), \\
& C_{H}^{*}\left(s^{t}\right)=\left(\frac{\gamma}{1-\gamma}\right)^{1-\gamma}\left(\frac{\bar{P}_{H}^{*}\left(s^{t}\right)}{\bar{P}_{F}^{*}\left(s^{t}\right)}\right)^{-(1-\gamma)} C^{*}\left(s^{t}\right), \\
& \bar{P}_{H}^{*}\left(s^{t}\right)=\frac{\bar{P}_{H}\left(s^{t}\right)}{\bar{e}\left(s^{t}\right)}(1+\phi) \\
& \bar{M}^{*}\left(s^{t-1}\right)+\bar{X}_{t}^{*} \geq \bar{P}^{*}\left(s^{t}\right) C^{*}\left(s^{t}\right) . \\
& \bar{P}_{F}^{*}\left(s^{t}\right) C_{F}^{*}\left(s^{t}\right)+\bar{P}_{H}^{*}\left(s^{t}\right) C_{H}^{*}\left(s^{t}\right)=\bar{P}^{*}\left(s^{t}\right) C^{*}\left(s^{t}\right) \\
& Y\left(s^{t}\right)=C_{H}\left(s^{t}\right)+C_{H}^{*}\left(s^{t}\right)(1+\phi)+Z\left(s^{t}\right)+G_{t} . \\
& Y^{*}\left(s^{t}\right)=C_{F}^{*}\left(s^{t}\right)+C_{F}\left(s^{t}\right)(1+\phi)+Z^{*}\left(s^{t}\right)+G_{t}^{*} \text {, } \\
& \frac{\bar{W}\left(s^{t}\right)}{\bar{P}_{H}\left(s^{t}\right)}=\frac{\alpha_{h} Y\left(s^{t}\right)}{R\left(s^{t}\right) H\left(s^{t}\right)} \\
& \frac{\bar{W}\left(s^{t}\right)}{\bar{P}\left(s^{t}\right)}=-\frac{U_{L}\left(s^{t}\right)}{U_{C}\left(s^{t}\right)} \\
& \frac{\bar{W}^{*}\left(s^{t}\right)}{\bar{P}_{F}^{*}\left(s^{t}\right)}=\frac{\alpha_{h} Y^{*}\left(s^{t}\right)}{R^{*}\left(s^{t}\right) H^{*}\left(s^{t}\right)} \\
& \frac{\bar{W}^{*}\left(s^{t}\right)}{\bar{P}^{*}\left(s^{t}\right)}=-\frac{U_{L}^{*}\left(s^{t}\right)}{U_{C}^{*}\left(s^{t}\right)}
\end{aligned}
$$




$$
\begin{gathered}
\bar{M}\left(s^{t-1}\right)-\bar{D}\left(s^{t-1}\right)+\bar{W}\left(s^{t}\right) L\left(s^{t}\right) \geq \bar{P}\left(s^{t}\right) C\left(s^{t}\right) \\
Z\left(s^{t}\right)=K\left(s^{t}\right)-(1-\delta) K\left(s^{t-1}\right) \\
Y\left(s^{t}\right)=A_{t} H\left(s^{t}\right)^{\alpha_{h}} K\left(s^{t-1}\right)^{\alpha_{k}} \\
\bar{D}\left(s^{t-1}\right)+\bar{X}_{t}=\bar{W}\left(s^{t}\right) H\left(s^{t}\right) \\
\bar{M}^{*}\left(s^{t-1}\right)-\bar{D}^{*}\left(s^{t-1}\right)+\bar{W}^{*}\left(s^{t}\right) L^{*}\left(s^{t}\right) \geq \bar{P}^{*}\left(s^{t}\right) C^{*}\left(s^{t}\right) \\
Z^{*}\left(s^{t}\right)=K^{*}\left(s^{t}\right)-(1-\delta) K^{*}\left(s^{t-1}\right) \\
Y^{*}\left(s^{t}\right)=A_{t}^{*} H^{*}\left(s^{t}\right)^{\alpha_{h}} K^{*}\left(s^{t-1}\right)^{\alpha_{k}} \\
\bar{D}^{*}\left(s^{t-1}\right)+\bar{X}_{t} \geq \bar{W}^{*}\left(s^{t}\right) H^{*}\left(s^{t}\right) \\
G_{t}=T_{t} \\
G_{t}^{*}=T_{t}^{*}
\end{gathered}
$$

\section{Expectational equations}

$$
\begin{aligned}
& E\left[\frac{U_{c}\left(s^{t}\right)}{\bar{P}\left(s^{t}\right)} \mid s^{t-1}\right]=\beta E\left[R\left(s^{t}\right) \frac{U_{c}\left(s^{t+1}\right)}{\bar{P}\left(s^{t+1}\right)} \mid s^{t-1}\right] \\
& E\left[\frac{U_{c}\left(s^{t+1}\right)}{\bar{P}\left(s^{t+1}\right)} \bar{P}_{H}\left(s^{t}\right) \mid s^{t}\right]=\beta E\left[\frac{U_{c}\left(s^{t+2}\right)}{\bar{P}\left(s^{t+2}\right)}\left(\frac{\alpha_{k} \bar{P}_{H}\left(s^{t+1}\right) Y\left(s^{t+1}\right)}{K\left(s^{t}\right)}+(1-\delta) \bar{P}_{H}\left(s^{t+1}\right)\right) \mid s^{t}\right] \\
& \bar{B}\left(s^{t}\right)=R^{B}\left(s^{t-1}\right) \bar{B}\left(s^{t-1}\right)+\bar{P}_{F}\left(s^{t}\right) C_{F}\left(s^{t}\right)-\bar{P}_{H}\left(s^{t}\right) C_{H}^{*}\left(s^{t}\right)(1+\phi) \\
& E\left[\frac{U_{c}\left(s^{t+1}\right)}{\bar{P}\left(s^{t+1}\right)} \mid s^{t}\right]=\beta E\left[R^{B}\left(s^{t}\right) \frac{U_{c}\left(s^{t+2}\right)}{\bar{P}\left(s^{t+2}\right)} \mid s^{t}\right] \\
& E\left[\frac{U_{c}^{*}\left(s^{t}\right)}{\bar{P}^{*}\left(s^{t}\right)} \mid s^{t-1}\right]=\beta E\left[R^{*}\left(s^{t}\right) \frac{U_{c}^{*}\left(s^{t+1}\right)}{\bar{P}^{*}\left(s^{t+1}\right)} \mid s^{t-1}\right] \\
& E\left[\frac{U_{c}^{*}\left(s^{t+1}\right)}{\bar{P}^{*}\left(s^{t+1}\right)} \bar{P}_{F}^{*}\left(s^{t}\right) \mid s^{t}\right]=\beta E\left[\frac{U_{c}^{*}\left(s^{t+2}\right)}{\bar{P}^{*}\left(s^{t+2}\right)}\left(\frac{\alpha_{k} \bar{P}_{F}^{*}\left(s^{t+1}\right) Y^{*}\left(s^{t+1}\right)}{K^{*}\left(s^{t}\right)}+(1-\delta) \bar{P}_{F}^{*}\left(s^{t+1}\right)\right) \mid s^{t}\right] \\
& \bar{B}^{*}\left(s^{t}\right)=R^{B *}\left(s^{t-1}\right) \bar{B}^{*}\left(s^{t-1}\right)+\bar{P}_{H}^{*}\left(s^{t}\right) C_{H}^{*}\left(s^{t}\right)-\bar{P}_{F}^{*}\left(s^{t}\right) C_{F}\left(s^{t}\right)(1+\phi) \\
& E\left[\frac{U_{c}^{*}\left(s^{t+1}\right)}{\bar{P}^{*}\left(s^{t+1}\right)} \mid s^{t}\right]=\beta E\left[R^{B *}\left(s^{t+1}\right) \frac{U_{c}^{*}\left(s^{t+2}\right)}{\bar{P}^{*}\left(s^{t+2}\right)} \mid s^{t}\right] \\
& R^{B}\left(s^{t}\right)=\frac{e\left(s^{t+1}\right)}{e\left(s^{t}\right)} R^{B *}\left(s^{t}\right)\left(\frac{1+X_{t}}{1+X_{t}^{*}}\right)
\end{aligned}
$$

and

$$
\bar{B}\left(s^{t}\right)+\bar{e}\left(s^{t}\right) \bar{B}^{*}\left(s^{t}\right)=0 .
$$


Complete set of equations: delivery costs model

\section{Contemporaneous equations}

$$
\begin{aligned}
& C\left(s^{t}\right)=C_{H}^{1-\gamma}\left(s^{t}\right) C_{F}^{\gamma}\left(s^{t}\right), \\
& C_{H}\left(s^{t}\right)=\left(\frac{1-\gamma}{\gamma}\right)^{\gamma}\left(\frac{\bar{P}_{H}\left(s^{t}\right)}{\bar{P}_{F}\left(s^{t}\right)}\right)^{-\gamma} C\left(s^{t}\right), \\
& C_{F}\left(s^{t}\right)=\left(\frac{\gamma}{1-\gamma}\right)^{1-\gamma}\left(\frac{\bar{P}_{F}\left(s^{t}\right)}{\bar{P}_{H}\left(s^{t}\right)}\right)^{-(1-\gamma)} C\left(s^{t}\right), \\
& \bar{M}\left(s^{t-1}\right)+\bar{X}_{t} \geq \bar{P}\left(s^{t}\right) C\left(s^{t}\right) . \\
& \bar{P}_{H}\left(s^{t}\right) C_{H}\left(s^{t}\right)+\bar{P}_{F}\left(s^{t}\right) C_{F}\left(s^{t}\right)=\bar{P}\left(s^{t}\right) C\left(s^{t}\right) \\
& \bar{P}_{H}\left(s^{t}\right) C_{H}\left(s^{t}\right)=(1-\gamma) \bar{P}\left(s^{t}\right) C\left(s^{t}\right) \\
& \bar{P}_{F}\left(s^{t}\right) C_{F}\left(s^{t}\right)=\gamma \bar{P}\left(s^{t}\right) C\left(s^{t}\right) \\
& \bar{P}_{F}\left(s^{t}\right)=\bar{e}\left(s^{t}\right) \bar{P}_{F}^{*}\left(s^{t}\right)+\phi \bar{P}_{H}\left(s^{t}\right) \\
& C^{*}\left(s^{t}\right)=C_{F}^{* 1-\gamma}\left(s^{t}\right) C_{H}^{* \gamma}\left(s^{t}\right) \\
& \bar{P}_{F}^{*}\left(s^{t}\right) C_{F}^{*}\left(s^{t}\right)=(1-\gamma) \bar{P}^{*}\left(s^{t}\right) C^{*}\left(s^{t}\right) \\
& \bar{P}_{H}^{*}\left(s^{t}\right) C_{H}^{*}\left(s^{t}\right)=\gamma \bar{P}^{*}\left(s^{t}\right) C^{*}\left(s^{t}\right) \\
& C_{F}^{*}\left(s^{t}\right)=\left(\frac{1-\gamma}{\gamma}\right)^{\gamma}\left(\frac{\bar{P}_{F}^{*}\left(s^{t}\right)}{\bar{P}_{H}^{*}\left(s^{t}\right)}\right)^{-\gamma} C^{*}\left(s^{t}\right), \\
& C_{H}^{*}\left(s^{t}\right)=\left(\frac{\gamma}{1-\gamma}\right)^{1-\gamma}\left(\frac{\bar{P}_{H}^{*}\left(s^{t}\right)}{\bar{P}_{F}^{*}\left(s^{t}\right)}\right)^{-(1-\gamma)} C^{*}\left(s^{t}\right), \\
& \bar{P}_{H}^{*}\left(s^{t}\right)=\frac{\bar{P}_{H}\left(s^{t}\right)}{\bar{e}\left(s^{t}\right)}+\phi \bar{P}_{F}^{*}\left(s^{t}\right) \\
& \bar{M}^{*}\left(s^{t-1}\right)+\bar{X}_{t}^{*} \geq \bar{P}^{*}\left(s^{t}\right) C^{*}\left(s^{t}\right) . \\
& \bar{P}_{F}^{*}\left(s^{t}\right) C_{F}^{*}\left(s^{t}\right)+\bar{P}_{H}^{*}\left(s^{t}\right) C_{H}^{*}\left(s^{t}\right)=\bar{P}^{*}\left(s^{t}\right) C^{*}\left(s^{t}\right) \\
& Y\left(s^{t}\right)=C_{H}\left(s^{t}\right)+C_{H}^{*}\left(s^{t}\right)+\phi C_{F}\left(s^{t}\right)+Z\left(s^{t}\right)+G_{t} \text {. } \\
& Y^{*}\left(s^{t}\right)=C_{F}^{*}\left(s^{t}\right)+C_{F}\left(s^{t}\right)+\phi C_{H}^{*}\left(s^{t}\right)+Z^{*}\left(s^{t}\right)+G_{t}^{*} \text {, } \\
& \frac{\bar{W}\left(s^{t}\right)}{\bar{P}_{H}\left(s^{t}\right)}=\frac{\alpha_{h} Y\left(s^{t}\right)}{R\left(s^{t}\right) H\left(s^{t}\right)} \\
& \frac{\bar{W}\left(s^{t}\right)}{\bar{P}\left(s^{t}\right)}=-\frac{U_{L}\left(s^{t}\right)}{U_{C}\left(s^{t}\right)} \\
& \frac{\bar{W}^{*}\left(s^{t}\right)}{\bar{P}_{F}^{*}\left(s^{t}\right)}=\frac{\alpha_{h} Y^{*}\left(s^{t}\right)}{R^{*}\left(s^{t}\right) H^{*}\left(s^{t}\right)} \\
& \frac{\bar{W}^{*}\left(s^{t}\right)}{\bar{P}^{*}\left(s^{t}\right)}=-\frac{U_{L}^{*}\left(s^{t}\right)}{U_{C}^{*}\left(s^{t}\right)}
\end{aligned}
$$




$$
\begin{gathered}
\bar{M}\left(s^{t-1}\right)-\bar{D}\left(s^{t-1}\right)+\bar{W}\left(s^{t}\right) L\left(s^{t}\right) \geq \bar{P}\left(s^{t}\right) C\left(s^{t}\right) \\
Z\left(s^{t}\right)=K\left(s^{t}\right)-(1-\delta) K\left(s^{t-1}\right) \\
Y\left(s^{t}\right)=A_{t} H\left(s^{t}\right)^{\alpha_{h}} K\left(s^{t-1}\right)^{\alpha_{k}} \\
\bar{D}\left(s^{t-1}\right)+\bar{X}_{t}=\bar{W}\left(s^{t}\right) H\left(s^{t}\right) \\
\bar{M}^{*}\left(s^{t-1}\right)-\bar{D}^{*}\left(s^{t-1}\right)+\bar{W}^{*}\left(s^{t}\right) L^{*}\left(s^{t}\right) \geq \bar{P}^{*}\left(s^{t}\right) C^{*}\left(s^{t}\right) \\
Z^{*}\left(s^{t}\right)=K^{*}\left(s^{t}\right)-(1-\delta) K^{*}\left(s^{t-1}\right) \\
Y^{*}\left(s^{t}\right)=A_{t}^{*} H^{*}\left(s^{t}\right)^{\alpha_{h}} K^{*}\left(s^{t-1}\right)^{\alpha_{k}} \\
\bar{D}^{*}\left(s^{t-1}\right)+\bar{X}_{t} \geq \bar{W}^{*}\left(s^{t}\right) H^{*}\left(s^{t}\right) \\
G_{t}=T_{t} \\
G_{t}^{*}=T_{t}^{*}
\end{gathered}
$$

\section{Expectational equations}

$$
\begin{gathered}
E\left[\frac{U_{c}\left(s^{t}\right) \mid}{\bar{P}\left(s^{t}\right)} \mid s^{t-1}\right]=\beta E\left[R\left(s^{t}\right) \frac{U_{c}\left(s^{t+1}\right)}{\bar{P}\left(s^{t+1}\right)} \mid s^{t-1}\right] \\
E\left[\frac{U_{c}\left(s^{t+1}\right)}{\bar{P}\left(s^{t+1}\right)} \bar{P}_{H}\left(s^{t}\right) \mid s^{t}\right]=\beta E\left[\frac{U_{c}\left(s^{t+2}\right)}{\bar{P}\left(s^{t+2}\right)}\left(\frac{\alpha_{k} \bar{P}_{H}\left(s^{t+1}\right) Y\left(s^{t+1}\right)}{K\left(s^{t}\right)}+(1-\delta) \bar{P}_{H}\left(s^{t+1}\right)\right) \mid s^{t}\right] \\
\bar{B}\left(s^{t}\right)=R^{B}\left(s^{t-1}\right) \bar{B}\left(s^{t-1}\right)+\bar{e}\left(s^{t}\right) \bar{P}_{F}^{*}\left(s^{t}\right) C_{F}\left(s^{t}\right)-\bar{P}_{H}\left(s^{t}\right) C_{H}^{*}\left(s^{t}\right) \\
E\left[\frac{U_{c}\left(s^{t+1}\right)}{\bar{P}\left(s^{t+1}\right)} \mid s^{t}\right]=\beta E\left[R^{B}\left(s^{t}\right) \frac{U_{c}\left(s^{t+2}\right)}{\bar{P}\left(s^{t+2}\right)} \mid s^{t}\right] \\
E\left[\frac{U_{c}^{*}\left(s^{t}\right)}{\bar{P}^{*}\left(s^{t}\right)} \mid s^{t-1}\right]=\beta E\left[R^{*}\left(s^{t}\right) \frac{U_{c}^{*}\left(s^{t+1}\right)}{\bar{P}^{*}\left(s^{t+1}\right)} \mid s^{t-1}\right] \\
\bar{P}^{*}\left(s^{t+1}\right) \\
\left.\bar{P}_{F}^{*}\left(s^{t}\right) \mid s^{t}\right]=\beta E\left[\frac{U_{c}^{*}\left(s^{t+2}\right)}{\bar{P}^{*}\left(s^{t+2}\right)}\left(\frac{\alpha_{k} \bar{P}_{F}^{*}\left(s^{t+1}\right) Y^{*}\left(s^{t+1}\right)}{K^{*}\left(s^{t}\right)}+(1-\delta) \bar{P}_{F}^{*}\left(s^{t+1}\right)\right) \mid s^{t}\right] \\
E\left[\frac{U_{c}^{*}\left(s^{t-1}\right) \bar{B}^{*}\left(s^{t-1}\right)+\frac{\bar{P}_{H}\left(s^{t}\right)}{\bar{e}\left(s^{t}\right)} C_{H}^{*}\left(s^{t}\right)-\bar{P}_{F}^{*}\left(s^{t}\right) C_{F}\left(s^{t}\right)}{\bar{P}^{*}\left(s^{t+1}\right)} \mid s^{t}\right]=\beta E\left[R^{B *}\left(s^{t+1}\right) \frac{U_{c}^{*}\left(s^{t+2}\right)}{\bar{P}^{*}\left(s^{t+2}\right)} \mid s^{t}\right] \\
R^{B}\left(s^{t}\right)=\frac{e\left(s^{t+1}\right)}{e\left(s^{t}\right)} R^{B *}\left(s^{t}\right)\left(\frac{1+X_{t}}{1+X_{t}^{*}}\right)
\end{gathered}
$$

and

$$
\bar{B}\left(s^{t}\right)+\bar{e}\left(s^{t}\right) \bar{B}^{*}\left(s^{t}\right)=0 .
$$




\section{Tables}

Table 1. Some business cycles data

\begin{tabular}{|c|c|c|c|c|}
\hline \multicolumn{5}{|c|}{ Data 1980:1-2001:2 } \\
\hline Country & USA & Japan & France & UK \\
\hline \multicolumn{5}{|c|}{ Relative standard deviations with respect to GDF } \\
\hline$G D P$ & 1 & 1 & 1 & 1 \\
\hline$C$ & 0.77 & 0.87 & 0.97 & 1.13 \\
\hline$Z$ & 4.04 & 3.04 & 4.94 & 4.43 \\
\hline$N X$ & 3.32 & 4.64 & 3.26 & 2.49 \\
\hline$C P I$ & 0.81 & 0.80 & 1.32 & 1.20 \\
\hline$M 1$ & 2.39 & 1.90 & 2.24 & 0.88 \\
\hline NIR & 1.20 & 0.68 & 1.74 & 1.09 \\
\hline$N E R$ & - & 8.82 & 9.81 & 5.18 \\
\hline$R E R$ & - & 7.50 & 2.46 & 3.81 \\
\hline \multicolumn{5}{|c|}{ Correlations with GDP* } \\
\hline$C$ & 0.83 & 0.63 & 0.73 & 0.87 \\
\hline$Z$ & 0.92 & 0.87 & 0.84 & 0.75 \\
\hline$N X$ & -0.40 & -0.33 & -0.23 & -0.31 \\
\hline$C P I$ & -0.46 & 0.06 & -0.02 & -0.50 \\
\hline$M 1$ & 0.06 & 0.33 & 0.24 & -0.0 \\
\hline$N I R$ & 0.45 & 0.48 & 0.37 & 0.26 \\
\hline$N E R$ & - & -0.44 & 0.03 & 0.26 \\
\hline$R E R$ & - & -0.59 & -0.28 & -0.01 \\
\hline$\rho(N E R, R E R)$ & - & 0.90 & 0.61 & 0.51 \\
\hline \multicolumn{5}{|c|}{ Autocorrelations } \\
\hline$G D P$ & 0.81 & 0.71 & 0.87 & 0.83 \\
\hline$N E R$ & - & 0.78 & 0.70 & 0.68 \\
\hline$R E R$ & - & 0.83 & 0.77 & 0.73 \\
\hline
\end{tabular}

Sources: OECD Main Economic Indicators (GDP: real GDP; $C$ : total private consumption in constant prices; $Z$ : gross fixed capital formation plus inventory change, in constant prices; $N X$ : net exports; $C P I$ : consumer price index; $M 1$ : money supply; NIR: nominal short-term interest rate); and NER: nominal exchange rate units of US\$ (domestic currency) per unit of foreign currency (Japan, UK, France); $R E R$ : real exchange rate based on relative CPIs.

* The correlations are for each variable with each country's own output. 
Table 2. Unconditional second order moments

\begin{tabular}{|c|c|c|c|c|c|c|c|}
\hline & \multicolumn{2}{|c|}{$(1972: 1-1994: 4)$} & \multirow{2}{*}{$\begin{array}{c}\text { Model } \\
\text { without } \\
\text { costs }\end{array}$} & \multicolumn{2}{|c|}{$\begin{array}{c}\text { Iceberg } \\
\text { costs }\end{array}$} & \multicolumn{2}{|c|}{$\begin{array}{c}\text { Delivery } \\
\text { costs }\end{array}$} \\
\hline & $\mathrm{US}^{12}$ & Europe & & (1) & (2) & (1) & (2) \\
\hline$\sigma_{y}$ & 1.82 & 1.13 & 1.08 & 1.08 & 1.07 & 1.08 & 1.07 \\
\hline$\sigma_{c}$ & 1.50 & 0.93 & 0.86 & 0.86 & 0.70 & 0.85 & 0.71 \\
\hline$\sigma_{l}$ & 1.21 & 0.74 & 0.32 & 0.32 & 0.36 & 0.32 & 0.36 \\
\hline$\sigma_{z}$ & 5.05 & 2.69 & 2.79 & 2.79 & 2.82 & 2.78 & 2.81 \\
\hline$\sigma_{e}$ & - & 8.51 & 2.35 & 2.35 & 2.03 & 2.35 & 2.03 \\
\hline$\sigma_{q}$ & - & 7.93 & 0.36 & 0.36 & 0.51 & 0.37 & 0.53 \\
\hline$\rho(y, c)$ & 0.87 & 0.81 & 0.67 & 0.67 & 0.64 & 0.68 & 0.65 \\
\hline$\rho(y, h)$ & 0.91 & 0.68 & 0.74 & 0.74 & 0.80 & 0.74 & 0.80 \\
\hline$\rho(y, z)$ & 0.95 & 0.86 & 0.85 & 0.85 & 0.91 & 0.85 & 0.91 \\
\hline$\rho\left(y, y_{-1}\right)$ & 0.87 & 0.85 & 0.76 & 0.76 & 0.45 & 0.76 & 0.45 \\
\hline$\rho\left(e, e_{-1}\right)$ & - & 0.86 & 0.34 & 0.34 & 0.23 & 0.34 & 0.23 \\
\hline$\rho\left(q, q_{-1}\right)$ & - & 0.83 & 0.74 & 0.74 & 0.72 & 0.74 & 0.72 \\
\hline$\rho(q, e)$ & - & 0.99 & -0.01 & -0.01 & -0.02 & 0.004 & 0.005 \\
\hline$\rho(e, y)$ & - & 0.31 & 0.05 & 0.05 & 0.05 & 0.05 & 0.06 \\
\hline$\rho(q, y)$ & - & 0.30 & 0.59 & 0.59 & 0.66 & 0.59 & 0.65 \\
\hline
\end{tabular}

(1) Unconditional moments, cross-country spillovers

(2) Unconditional moments, no cross-country spillovers

Table 3: Cross-country correlations

\begin{tabular}{l|cccc}
\hline \hline \multicolumn{2}{c}{ US-EUROPE } & $\begin{array}{c}\text { Model } \\
\text { without } \\
\text { costs }\end{array}$ & $\begin{array}{c}\text { Iceberg } \\
\text { costs }\end{array}$ & $\begin{array}{c}\text { Delivery } \\
\text { costs }\end{array}$ \\
\hline$\rho\left(y, y^{*}\right)$ & 0.6039 & 0.1824 & 0.1824 & 0.1902 \\
$\rho\left(c, c^{*}\right)$ & 0.3827 & 0.7781 & 0.7781 & 0.7789 \\
$\rho\left(z, z^{*}\right)$ & 0.5298 & 0.0648 & 0.0648 & 0.0434 \\
\hline \hline
\end{tabular}

\footnotetext{
${ }^{12}$ Source of data for US and EUROPE: Chari, Kehoe and McGrattan (2001).
} 
Table 4: Conditional second order moments

\begin{tabular}{l|ccc|ccc|ccc}
\hline \hline & \multicolumn{3}{|c}{ Productivity shocks } & \multicolumn{3}{c}{ M.supply shocks } & \multicolumn{3}{c}{ Fiscal shocks } \\
\hline & IC & DC & NC & IC & DC & NC & IC & DC & NC \\
\hline$\sigma_{y}$ & 1.08 & 1.08 & 1.08 & 0.06 & 0.06 & 0.06 & 0.01 & 0.01 & 0.01 \\
$\sigma_{e}$ & 0 & 0.01 & 0 & 2.35 & 2.35 & 2.35 & 0 & 0.00 & 0 \\
$\sigma_{q}$ & 0.36 & 0.36 & 0.36 & 0.03 & 0.03 & 0.03 & 0.01 & 0.01 & 0.01 \\
$\rho\left(e, e_{-1}\right)$ & 0.69 & 0.68 & 0.69 & 0.34 & 0.34 & 0.34 & 0.70 & 0.70 & 0.69 \\
$\rho\left(q, q_{-1}\right)$ & 0.75 & 0.74 & 0.75 & 0.12 & 0.11 & 0.12 & 0.70 & 0.71 & 0.70 \\
$\rho(q, e)$ & 0.32 & 0.93 & 0.08 & -0.17 & -0.08 & -0.17 & 0.99 & 0.99 & 0.86 \\
$\rho(e, y)$ & -0.47 & 0.64 & -0.69 & 0.58 & 0.58 & 0.58 & -0.44 & -0.51 & -0.19 \\
$\rho(q, y)$ & 0.60 & 0.59 & 0.60 & -0.06 & -0.01 & -0.06 & -0.52 & -0.52 & -0.52 \\
\hline \hline
\end{tabular}

IC, DC and NC refer to iceberg, delivery and no costs, respectively.

Cross-country spillovers. 


\section{Figures}

Figure 1: VAR estimation. Positive monetary shock (a reduction to FFR).
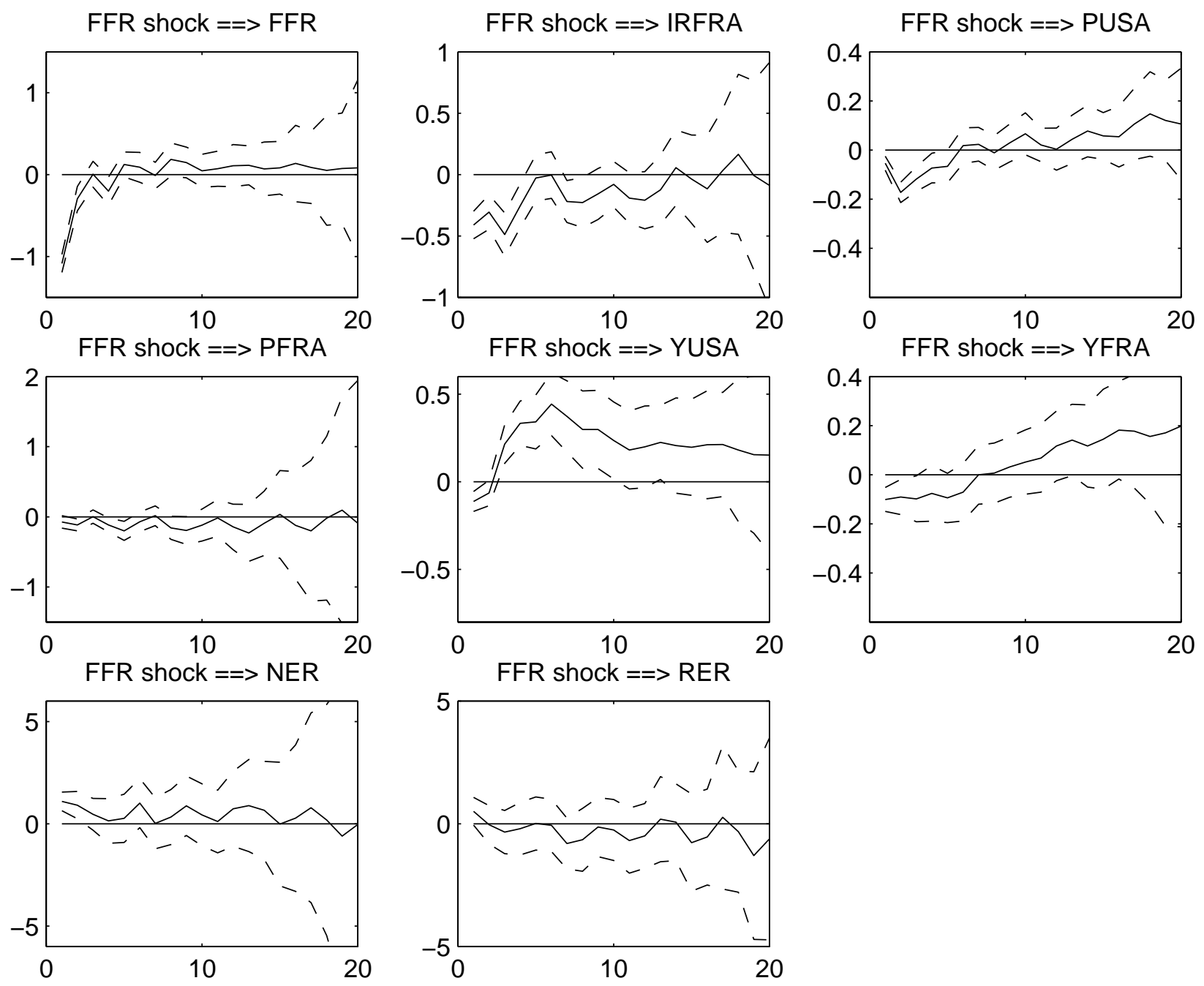
Figure 2: VAR estimation. Positive monetary shock (a reduction to FFR).
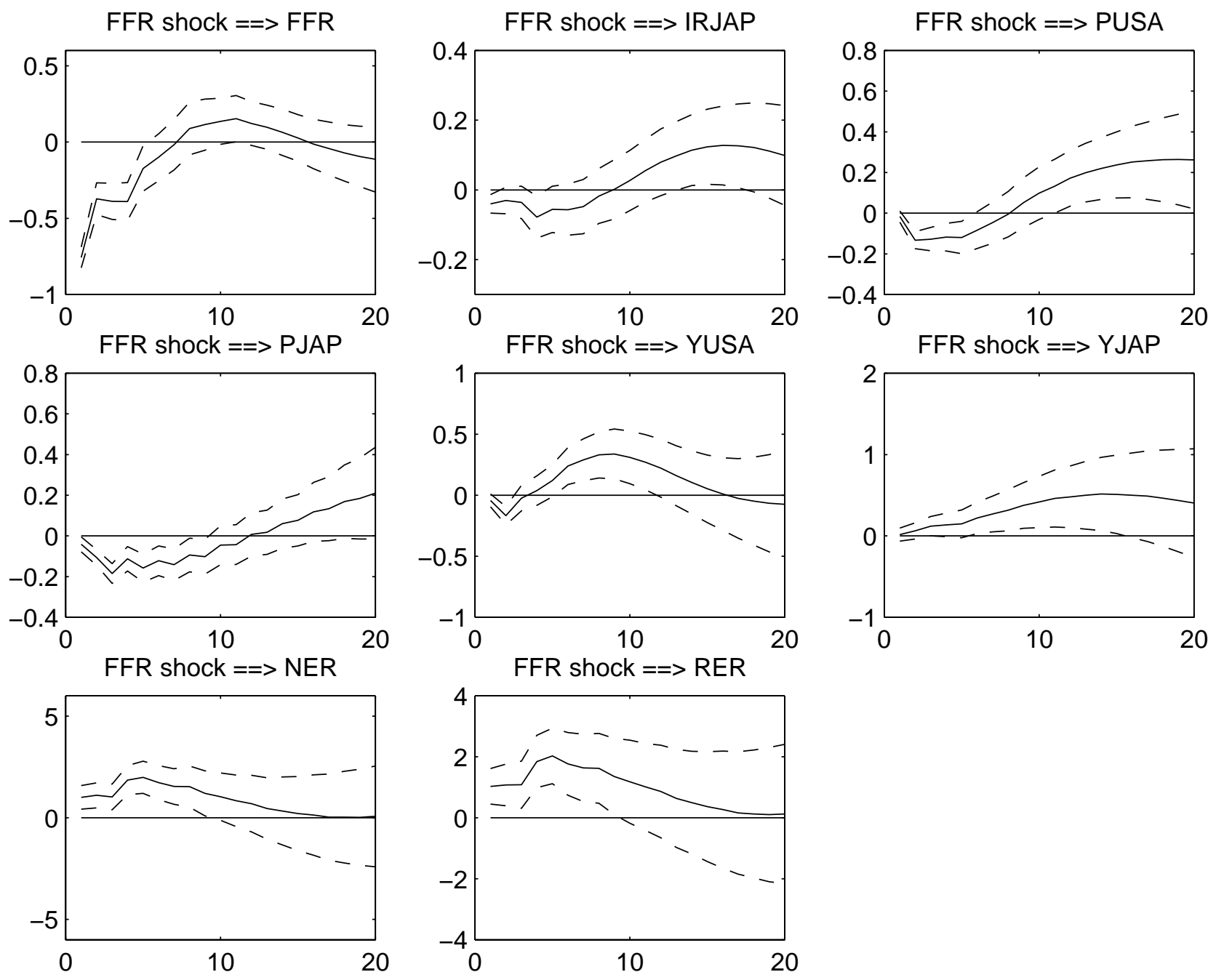
Figure 3: VAR estimation. Positive monetary shock (a reduction to FFR).
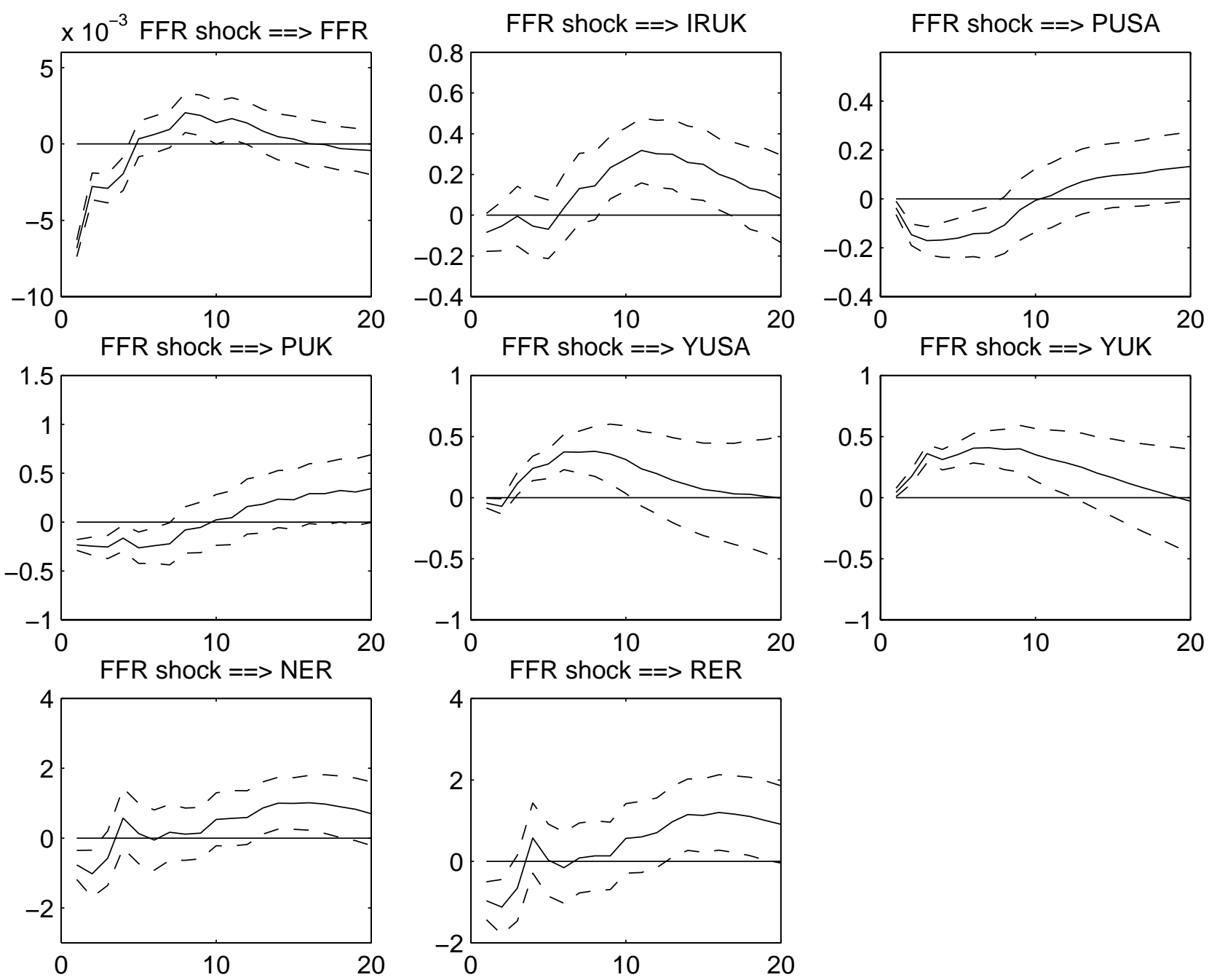
Figure 4: Impulse response functions of the model with iceberg costs to a one standard deviation increase in productivity at Home
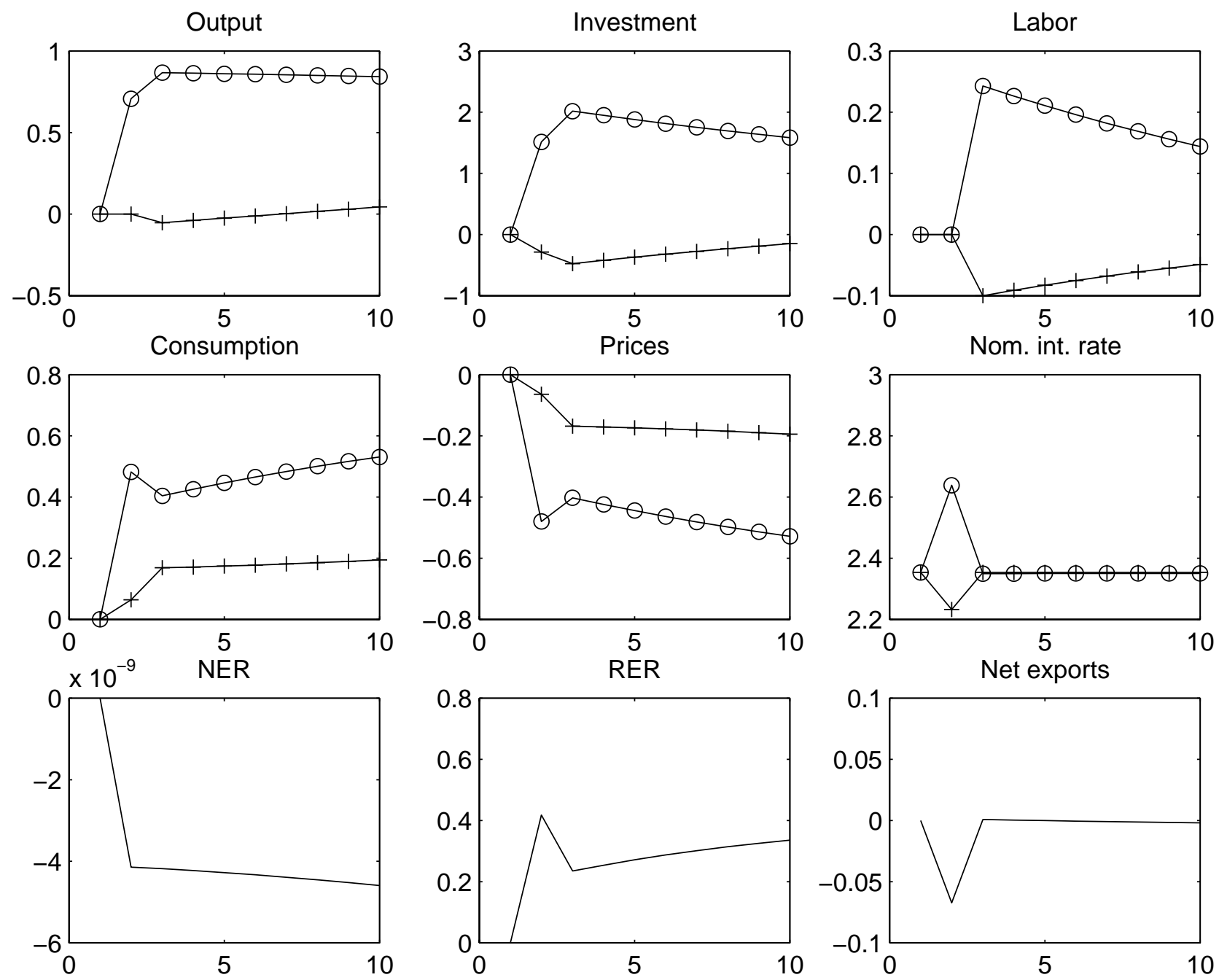

The dash-circled line refers to the Home country and the dash-crossed line to the Foreign country. All variables are plotted as percentage deviations from their steady state values except for the nominal interest rates that is in percentage units and net exports plotted as percentage of Home nominal GDP. 
Figure 5: Impulse response functions of the model with iceberg costs to a one standard deviation increase in money supply at Home
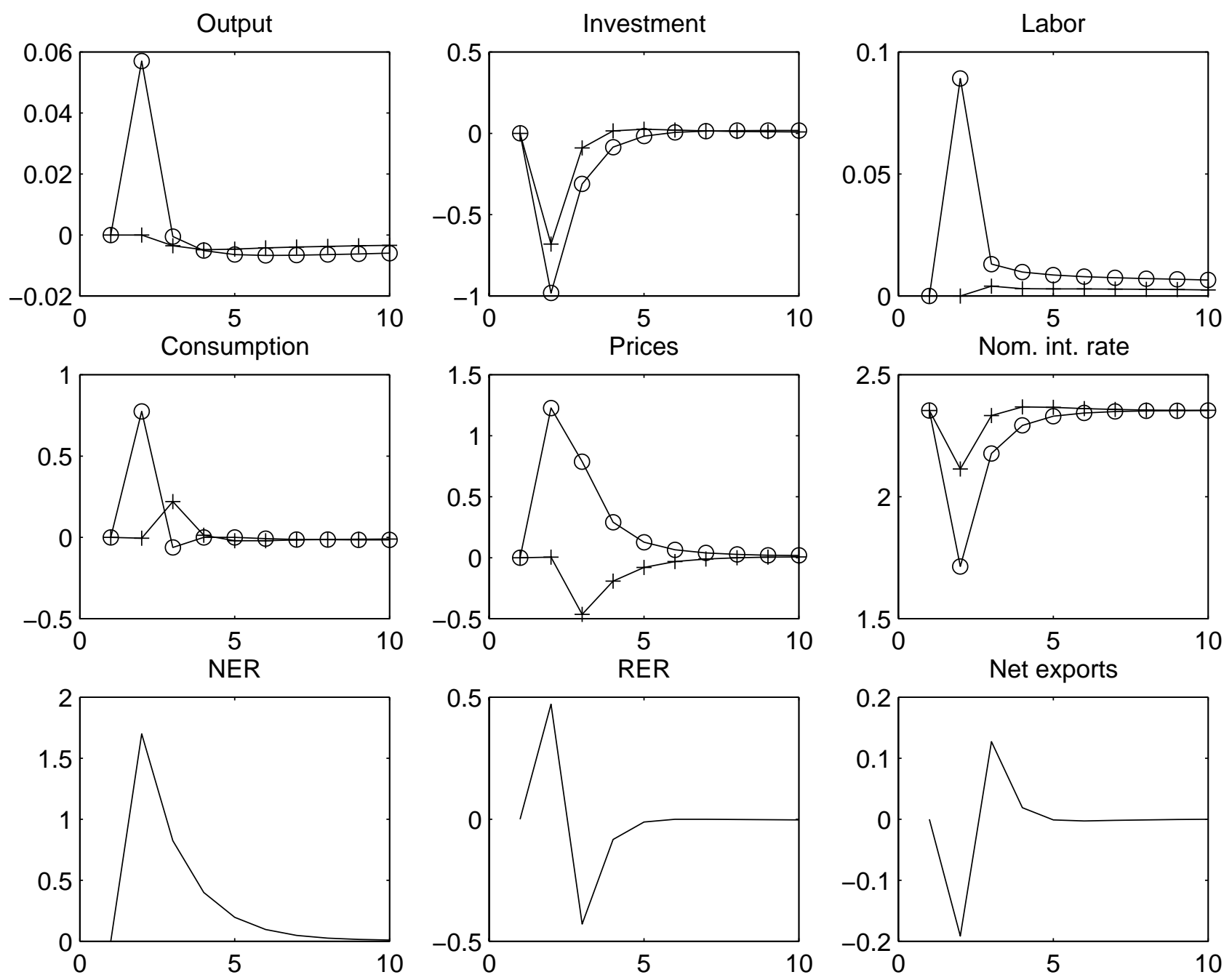

The dash-circled line refers to the Home country and the dash-crossed line to the Foreign country. All variables are plotted as percentage deviations from their steady state values except for the nominal interest rates that is in percentage units and net exports plotted as percentage of Home nominal GDP. 
Figure 6: Impulse response functions of the model with iceberg costs to a one standard deviation increase in government spending at Home
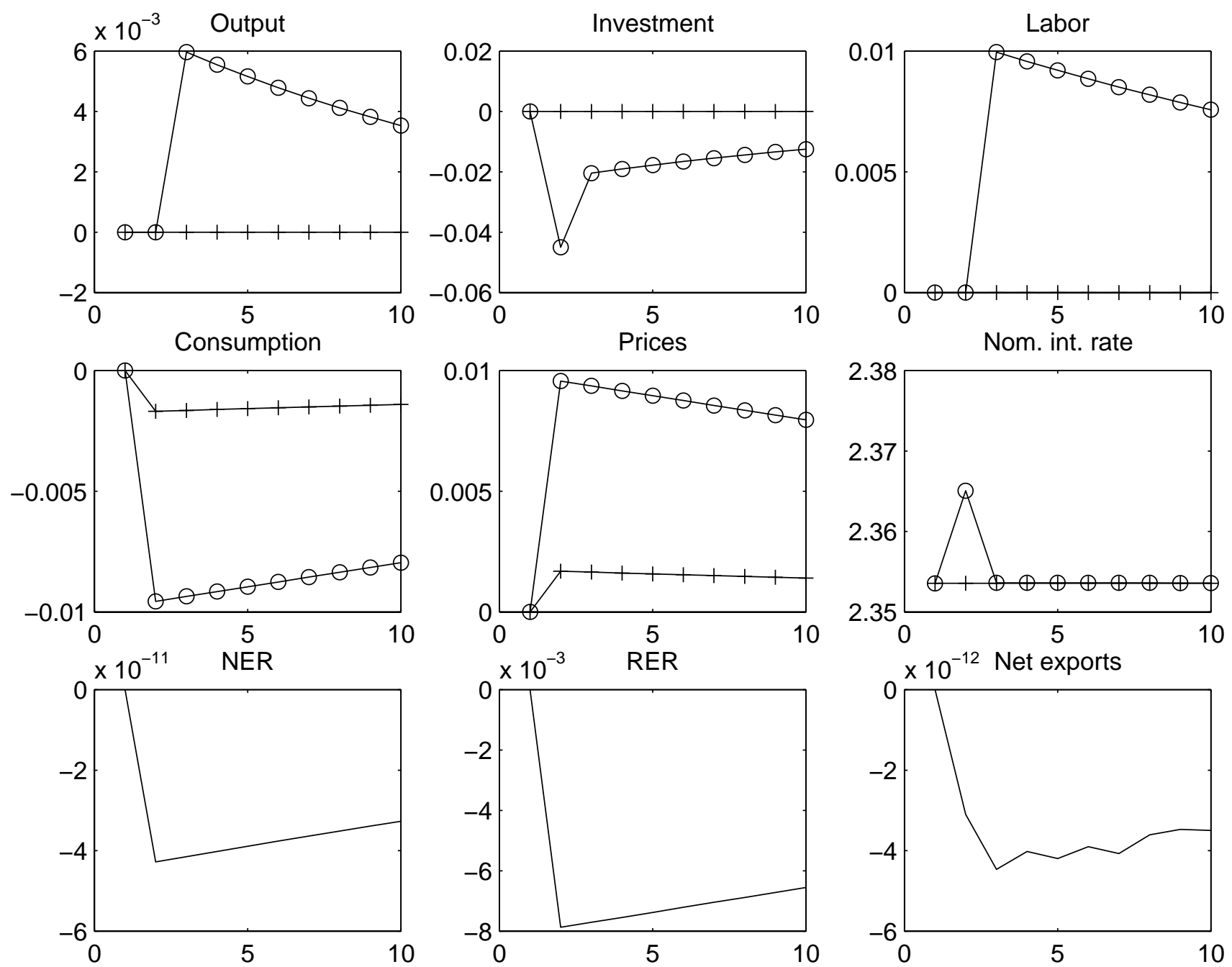

The dash-circled line refers to the Home country and the dash-crossed line to the Foreign country. All variables are plotted as percentage deviations from their steady state values except for the nominal interest rates that is in percentage units and net exports plotted as percentage of Home nominal GDP. 
Figure 7: Iceberg vs delivery costs: productivity shock
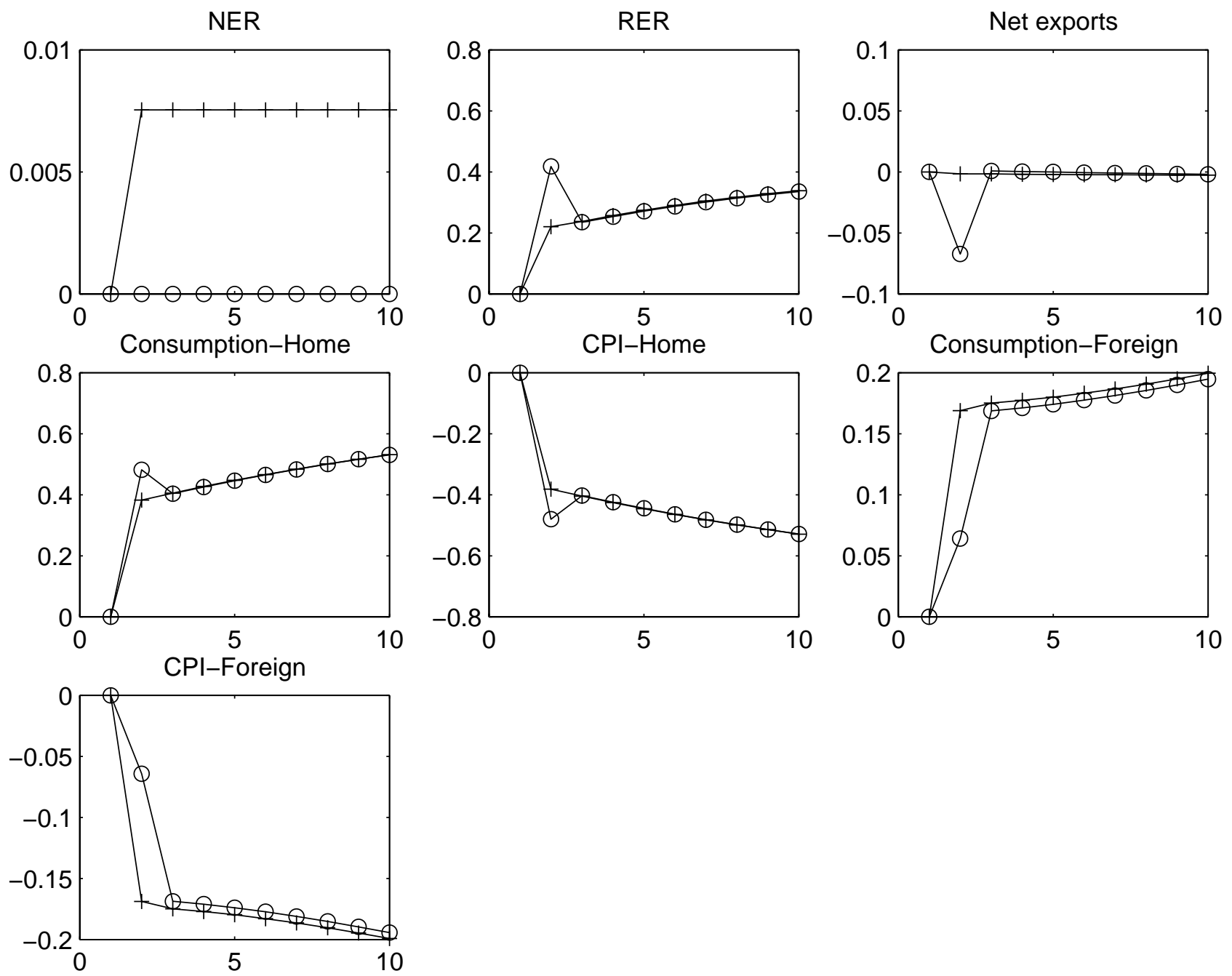

The dash-circled line refers to the iceberg cost model and the dash-crossed line to the delivery cost model. All variables are plotted as percentage deviations from their steady state values except for the nominal interest rates that is in percentage units and net exports plotted as percentage of Home nominal GDP. 
Figure 8: Iceberg vs delivery costs: money supply shock
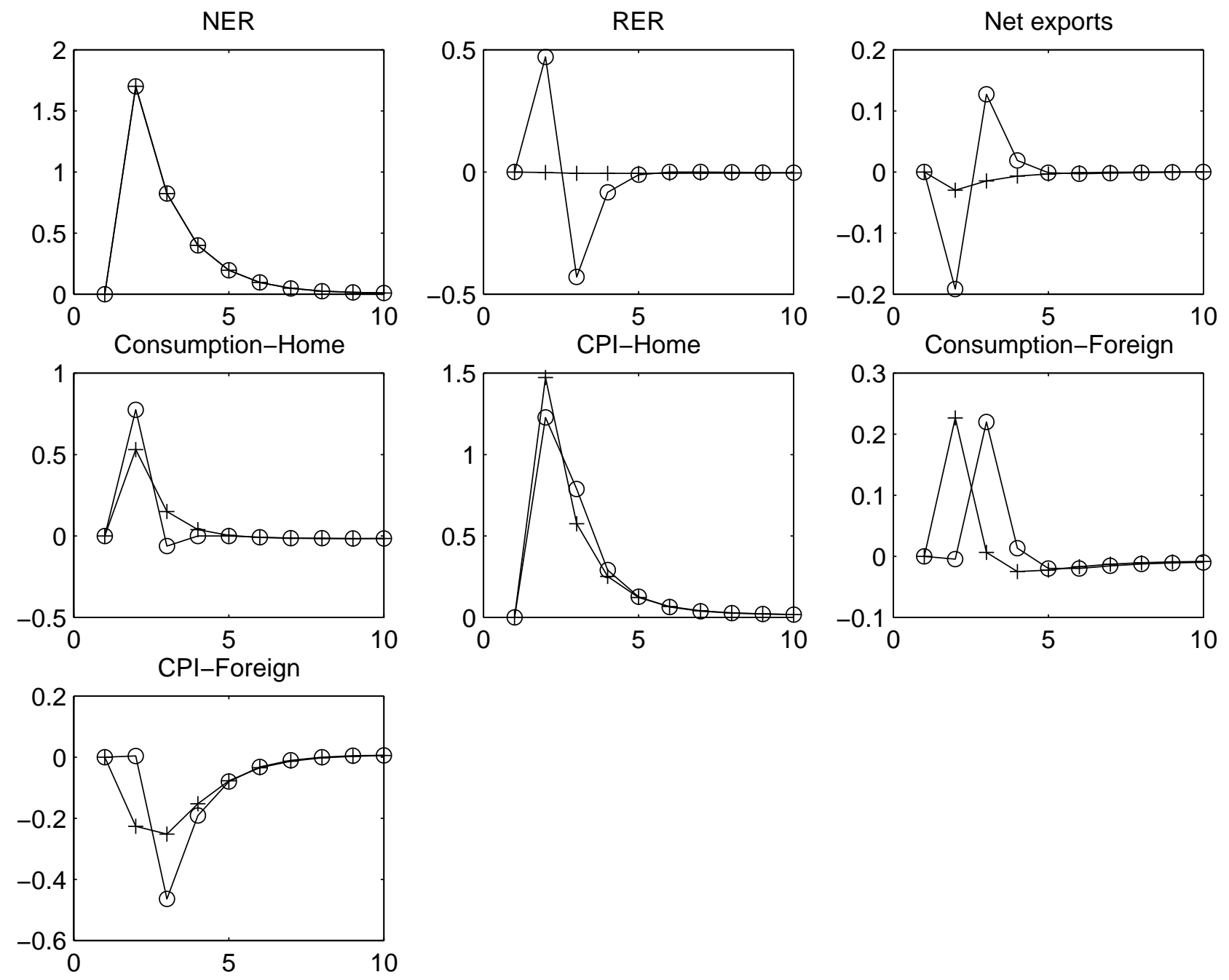

The dash-circled line refers to the iceberg cost model and the dash-crossed line to the delivery cost model. All variables are plotted as percentage deviations from their steady state values except for the nominal interest rates that is in percentage units and net exports plotted as percentage of Home nominal GDP. 
Figure 9: Iceberg vs delivery costs: fiscal shock
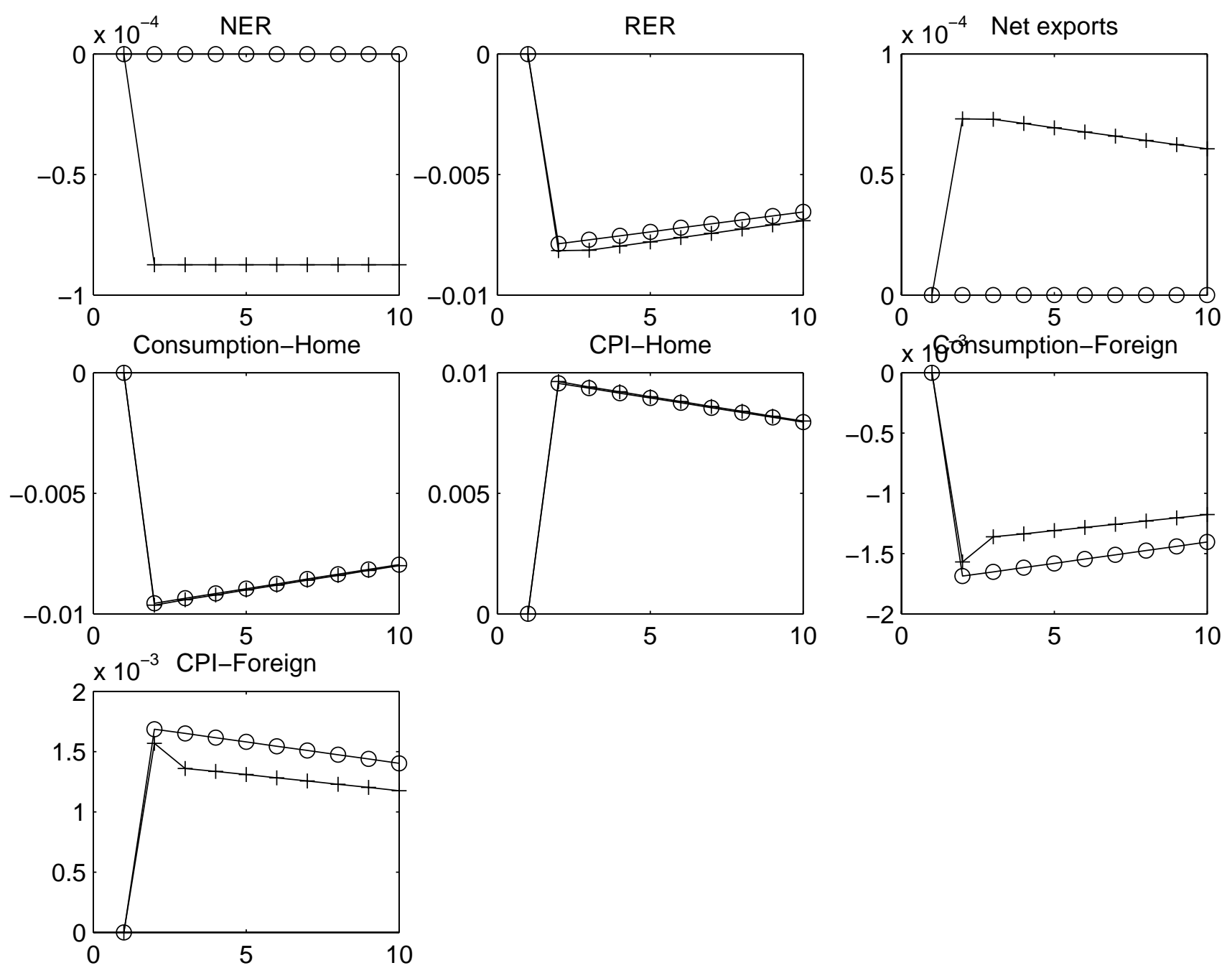

The dash-circled line refers to the iceberg cost model and the dash-crossed line to the delivery cost model. All variables are plotted as percentage deviations from their steady state values except for the nominal interest rates that is in percentage units and net exports plotted as percentage of Home nominal GDP. 


\section{BANCO DE ESPAÑA PUBLICATIONS}

\section{WORKING PAPERS ${ }^{1}$}

0501 ÓSCAR J. ARCE: The fiscal theory of the price level: a narrow theory for non-fiat money.

0502 ROBERT-PAUL BERBEN, ALBERTO LOCARNO, JULIAN MORGAN AND JAVIER VALLÉS: Cross-country differences in monetary policy transmission.

0503 ÁNGEL ESTRADA AND J. DAVID LÓPEZ-SALIDO: Sectoral mark-up dynamics in Spain.

0504 FRANCISCO ALONSO, ROBERTO BLANCO AND GONZALO RUBIO: Testing the forecasting performance of Ibex 35 option-implied risk-neutral densities.

0505 ALICIA GARCÍA-HERRERO AND ÁLVARO ORTIZ: The role of global risk aversion in explaining Latin American sovereign spreads.

0506 ALFREDO MARTíN, JESÚS SAURINA AND VICENTE SALAS: Interest rate dispersion in deposit and loan markets.

0507 MÁXIMO CAMACHO AND GABRIEL PÉREZ-QUIRÓS: Jump-and-rest effect of U.S. business cycles.

0508 LUIS J. ÁLVAREZ, PABLO BURRIEL AND IGNACIO HERNANDO: Do decreasing hazard functions for price changes make any sense?

0509 ÁNGEL DE LA FUENTE AND JUAN F. JIMENO: The private and fiscal returns to schooling and the effect of public policies on private incentives to invest in education: a general framework and some results for the EU.

0510 JUAN J. DOLADO, MARCEL JANSEN AND JUAN F. JIMENO: Dual employment protection legislation: a framework for analysis.

0511 ANA DEL RÍO AND GARRY YOUNG: The determinants of unsecured borrowing: evidence from the British household panel survey.

0512 ANA DEL RÍO AND GARRY YOUNG: The impact of unsecured debt on financial distress among British households.

0513 ADELA LUQUE: Skill mix and technology in Spain: evidence from firm-level data.

0514 J. DAVID LÓPEZ-SALIDO, FERNANDO RESTOY AND JAVIER VALLÉS: Inflation differentials in EMU: The Spanish case.

0515 ISAAC ALFON, ISABEL ARGIMÓN AND PATRICIA BASCUÑANA-AMBRÓs: How individual capital requirements affect capital ratios in UK banks and building societies.

0516 JOSÉ MANUEL CAMPA AND IGNACIO HERNANDO: M\&As performance in the European financial industry.

0517 ALICIA GARCÍA-HERRERO AND DANIEL SANTABÁRBARA: Does China have an impact on foreign direct investment to Latin America?

0518 MAXIMO CAMACHO, GABRIEL PEREZ-QUIROS AND LORENA SAIZ: Do European business cycles look like one?

0519 DANIEL PÉREZ, VICENTE SALAS-FUMÁS AND JESÚS SAURINA: Banking integration in Europe.

0520 JORDI GALÍ, MARK GERTLER AND J. DAVID LÓPEZ-SALIDO: Robustness of the estimates of the hybrid New Keynesian Phillips curve.

0521 JAVIER ANDRÉS, J. DAVID LÓPEZ-SALIDO AND EDWARD NELSON: Sticky-price models and the natural rate hypothesis.

0522 OLYMPIA BOVER: Wealth effects on consumption: microeconometric estimates from the Spanish survey of household finances.

0523 ENRIQUE ALBEROLA, LUIS MOLINA AND DANIEL NAVIA: Say you fix, enjoy and relax: the deleterious effect of peg announcements on fiscal discipline.

0524 AGUSTÍN MARAVALL: An application of the TRAMO SEATS automatic procedure; direct versus indirect adjustment.

0525 ALICIA GARCÍA-HERRERO AND MARÍA SOLEDAD MARTÍNEZ-PERÍA: The mix of international banks' foreign claims: determinants and implications for financial stability.

0526 J. IGNACIO GARCÍA-PÉREZ AND JUAN F. JIMENO: Public sector wage gaps in Spanish regions.

0527 LUIS J. ÁLVAREZ, PABLO BURRIEL AND IGNACIO HERNANDO: Price setting behaviour in Spain: evidence from micro PPI data.

1. Previously published Working Papers are listed in the Banco de España publications calalogue. 
0528 EMMANUEL DHYNE, LUIS J. ÁLVAREZ, HERVÉ LE BIHAN, GIOVANNI VERONESE, DANIEL DIAS, JOHANNES HOFFMANN, NICOLE JONKER, PATRICK LÜNNEMANN, FABIO RUMLER AND JOUKO VILMUNEN: Price setting in the euro area: some stylized facts from individual consumer price data.

0529 TERESA SASTRE AND JOSÉ LUIS FERNÁNDEZ-SÁNCHEZ: Un modelo empírico de las decisiones de gasto de las familias españolas.

0530 ALFREDO MARTÍN-OLIVER, VICENTE SALAS-FUMÁS AND JESÚS SAURINA: A test of the law of one price in retail banking.

0531 GABRIEL JIMÉNEZ AND JESÚS SAURINA: Credit cycles, credit risk, and prudential regulation.

0532 BEATRIZ DE-BLAS-PÉREZ: Exchange rate dynamics in economies with portfolio rigidities.

\begin{tabular}{|c|c|}
\hline & Unidad de Publicaciones \\
Alcalá, 522; 28027 Madrid \\
BANCODEESPANA & Telephone +34 91 3386363 . Fax +34 913386488 \\
e-mail: Publicaciones@bde.es \\
www.bde.es
\end{tabular}




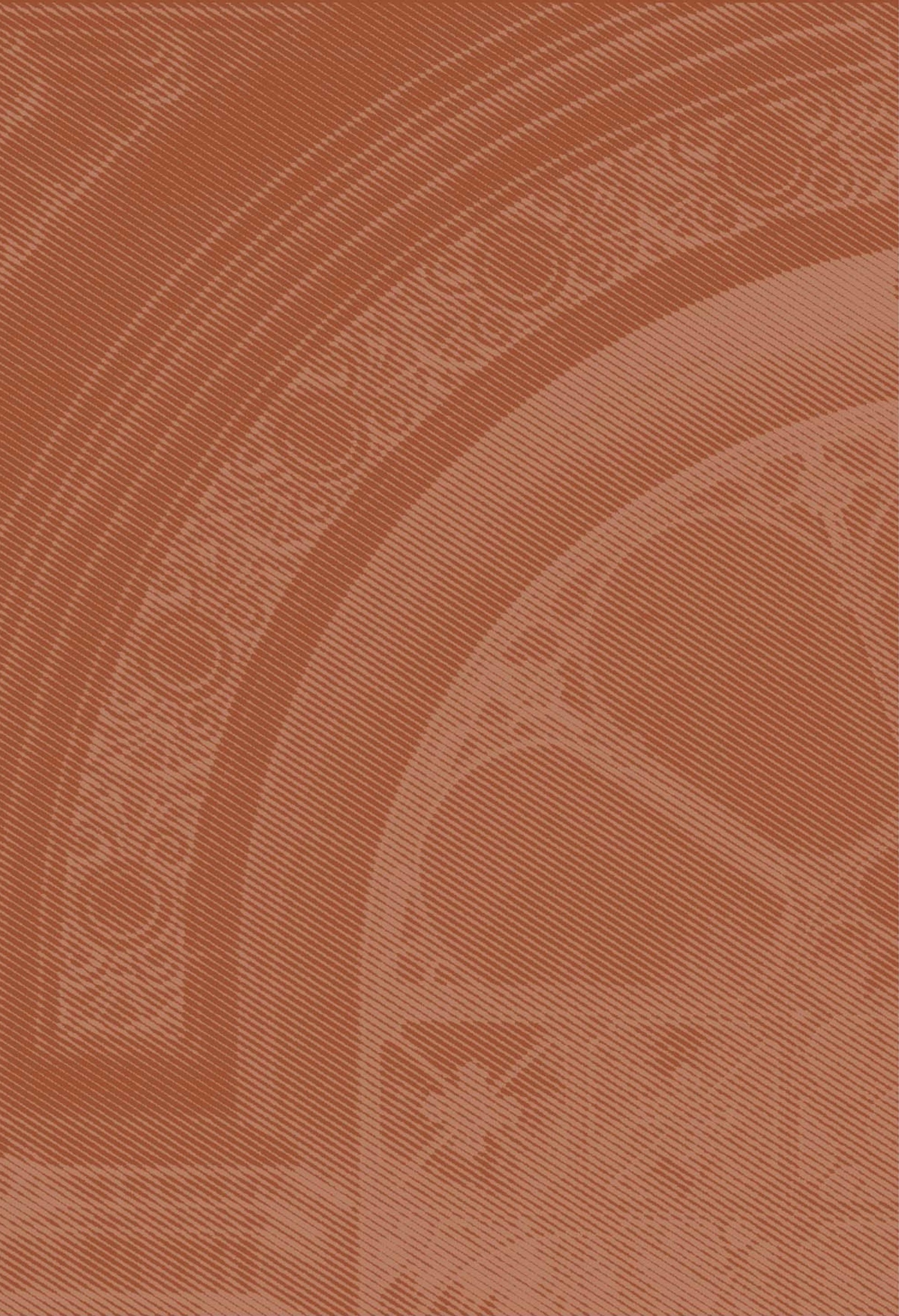

